\title{
PAD SAVEZNIČKOG ZRAKOPLOVA BRISTOL BEAUFIGHTERA (NT997) KOD SENJA U LISTOPADU 1944. GODINE
}

\author{
Posvećeno uspomeni na F/Lt. Alana Russella \\ Vancea i Lt. Alexandra Morrisa Medalieja
}

Pio Domines Peter

UDK: 94(497.5Senj) “1944”

Ante Starčevića 31

Stručni članak

HR 53270 Senj

21.07.2019.

peter.pio@hotmail.com

Ključni vojnostrateški položaj i iznimno prometno, gospodarsko i vojno značenje senjske luke glavni su razlozi zbog kojih je Senj tijekom Drugog svjetskog rata pretrpio strahovita zračna bombardiranja njemačkih, a potom i savezničkih zračnih snaga koja su rezultirala ljudskim gubicima i znatnom materijalnom štetom.

Od početka 1944. godine, kada savezničko zrakoplovstvo ostvaruje premoć u zraku, pa sve do kraja rata, senjska luka i lučki objekti bili su česta meta savezničkih taktičkih zračnih bombardiranja, ali i poprište ciljanih napada lovaca i lovaca bombardera usmjerenih na manje, specifične i posebno planirane ciljeve. U arhivskim dokumentima zabilježen je veći broj zračnih napada na Senj, a u jednoj od misija savezničkih zračnih snaga 10. listopada 1944. godine djelovanjem protuzračne obrane s njemačkog broda Arpione u senjskoj luci oboren je lovac-bombarder Bristol Beaufighter NT997 iz sastava 19. eskadrile Južnoafričkog ratnog zrakoplovstva (SAAF) koji se srušio u more nedaleko luke.

Rasvjetljivanje okolnosti pada i sudbina članova posade analizom ostataka zrakoplova i prikupljenih arhivskih dokumenata glavni su ciljevi ovog rada, koji nastaje u svjetlu 75. obljetnice toga događaja.

Ključne riječi: Drugi svjetski rat, Senj, pad zrakoplova, Bristol Beaufighter, Arpione

\section{Uvod}

Među mnogim taktičkim i tehnološkim dostignućima i novinama koji su obilježili Drugi svjetski rat, nijedan ratni stroj nije imao toliko presudnu važnost u odlučivanju i usmjeravanju tijeka ratnih bitaka kao vojni zrakoplovi koji su 
masovno proizvođeni i upotrebljavani kao potpora pomorskim ili kopnenim jedinicama, ali i kao nositelji ključne uloge u strateškom bombardiranju ciljeva duboko u neprijateljskoj pozadini. U takvim dalekometnim misijama često su razoreni čitavi gradovi, praćeni stradavanjem masovnog broja civilnih žrtava što je, među ostalim, Drugom svjetskom ratu priskrbilo epitet "totalnog rata". Međutim, neizbježna posljedica intenzivnih zračnih operacija bili su česti i brojni gubitci samih zrakoplova, a upravo njihove olupine, prisutne na gotovo svim bojišnicama i bitkama u kojima su sudjelovale zračne snage, predstavljaju važnu i zanimljivu kategoriju kulturno-povijesne i vojne baštine.

Kao i diljem svijeta koji je proživio pakao rata, olupine zrakoplova srušenih na području Hrvatske dio su nepokretne materijalne baštine Drugog svjetskog rata koju se podjednako može susresti diljem našeg podmorja i kopna. Međutim, unatoč njihovoj razmjernoj brojnosti, tek rijetki od njih poput savezničkih bombardera tipa B-17 i B-24 u akvatoriju otoka Visa, ${ }^{1}$ bombardera tipa B-24 koji su se srušili kod Sućurja na otoku Hvara² i u blizini Vrsara ${ }^{3}$ te olupine njemačkog zrakoplova Ju-87 u podmorju otoka Žirja ${ }^{4}$ zbog svoje iznimne vrijednosti povijesnog artefakta uživaju status kulturnog dobra. ${ }^{5}$ Posebno treba naglasiti da su te olupine i njihove povijesne priče otkrivene i rasvijetljene ponajprije zalaganjem samostalnih istraživača jer, unatoč

${ }^{1}$ B-17G 44-6630 iz 340. eskadrila 97. bombarderske grupe je 6. studenog 1944. prinudno sletio na površinu mora u blizini obale otoka Visa (nepokretno kulturno dobro Z-17) (D. FRKA - J. MESIĆ, 2012, 280-285).

B-24 J 42-51430 "Tulsamerican" iz sastava 765. eskadrila 461. bombarderske grupe je 17. prosinca 1944. grubo sletio na površinu mora nedaleko otoka Visa (nepokretno kulturno dobro Z-6743) (D. FRKA - J. MESIĆ, 2012, 271-279).

${ }^{2}$ B-24 J-15FO 42-51874 "Le Petite Fleur" iz 727. eskadrila 451. bombarderske grupe je 20. studenog 1944. grubo sletio na površinu mora zapadno od Sućurja na otoku Hvaru (nepokretno kulturno dobro Z-6527) (D. FRKA - J. MESIĆ, 2012, 262-269).

${ }^{3}$ B-24H-15-FO S 42-52655 "The Feather Merchant" iz 824. eskadrile 484 bombarderske grupe srušio se 13. lipnja 1944. u more ispred Vrsara (nepokretno kulturno dobro P-6070) (https:// www.min-kulture.hr/default.aspx?id=6212\&kdId=384781481) (2019-08-11)

${ }^{4}$ Junkers Ju-87 Stuka $R-2$ iz 239. eskadrile 97. grupe obrušavajućih bombardera Talijanskog ratnog zrakoplovstva prinudno je sletio na površinu mora u blizini otoka Žirja (nepokretno kulturno dobro P-4932) (o olupini vidi: https://gorgonija.com/2017/07/13/achtungstuka/) (2019-05-20)

5 Iznimna očuvanost olupine uz specifičnost i rijetkost tipa zrakoplova, povezanost s značajnim pojedincima ili događajima te mogućnost prezentacije glavni su kriteriji koji određuju njihovu visoku kulturno-povijesnu vrijednost, pa sukladno tome i razlozi koji zahtijevaju visok stupanj praktične zaštite. 
iznimnom istraživačkom potencijalu koje nudi istraživanje olupina gdje se arheološke metode mogu ispravno upotrebljavati u potkrjepljivanju povijesnih podataka, treba istaknuti da je zanimanje relevantnih stručnih institucija za istraživanje ovakvih lokaliteta na području Hrvatske tek u začecima. ${ }^{6}$

Brojnost srušenih zrakoplova nije iznenađujuća s obzirom na učestalost zračnih napada na pojedina mjesta na području Hrvatske, ali i tranzitni karakter hrvatskog zračnog prostora $u$ dalekometnim savezničkim zračnim operacijama usmjerenim na ciljeve u unutrašnjosti europskoga kopna. Prema dostupnim podatcima, od otprilike 500 zrakoplova izgubljenih na području Jugoslavije, gotovo polovicu toga broja čine saveznički zrakoplovi srušeni u razdoblju od konca 1943. pa sve do kraja rata. S druge strane, posljedice zračnih napada savezničkih, ali i osovinskih zračnih snaga na hrvatske gradove očituju se u materijalnoj šteti i ljudskim žrtvama koji kod mnogih hrvatskih gradova još nisu točno utvrđeni. ${ }^{7}$

\section{Zračna bombardiranja Senja u Drugom svjetskom ratu}

Među važnijim lukama, gospodarskim i prometnim središtima duž hrvatske obale nema mnogo mjesta na koja su zračna bombardiranjima tijekom Drugog svjetskog rata ostavila vječni i duboki trag na urbanističkoj i kulturnoj slici grada koliko na Senj. Početak rata Senj je dočekao kao značajno administrativno, gospodarsko i kulturno središte Hrvatskog primorja i šireg zaleđa. Izniman prometni položaj sa zaštićenom lukom na raskrsnici pomorskih i kopnenih putova i najkraća veza sa zaleđem bili su odlučujući čimbenici koju su Senju pridali iznimnu stratešku važnost i učinili ga izrazito poželjnim za sve sukobljene strane, stoga su od početka pa do kraja rata senjskim ulicama promarširale postrojbe različitih vojnih snaga.

Po raspadu Kraljevine Jugoslavije, u travnju 1941. godine u grad bez borbi ulazi talijanska vojska koja je za svoje potrebe zaposjela neke

${ }^{6}$ Mjesta pada savezničkih bombardera B-24 kod Oklaja u blizini Drniša i kod Krvavića nedaleko Marčane u Istri rijetki su primjeri takvih lokaliteta na kopnu koji su izazvali pažnju arheološke struke. O metodologiji istraživačkog rada, pronađenim ostatcima i povijesnim pričama tih zrakoplova usp. L. BEKIĆ, 2007, 197-211; M. SINOBAD, 2013-2014, 205-219.

${ }^{7}$ M. SINOBAD, 2013-2014, 206. Smatra se da su među hrvatskih gradovima u zračnim napadima najveću štetu pretrpjeli Zadar i Slavonski Brod, koji su imali i status "školskog primjera" bombardiranja u Drugom svjetskom ratu (M. KARAKAŠ OBRADOV, 2008, 30). Zbog mnogih poteškoća osobito je zahtjevno i problematično utvrđivanje ukupnog broja ljudskih žrtava, u koji treba uključiti i civilne i vojne žrtve. Opširnije o tome M. KARAKAŠ OBRADOV, 2008, 317-325. 
javne i stambene objekte i onemogućavala uspostavu tek osnovane ustaške vlasti. Međutim, potpisivanjem Rimskih ugovora, kojima je određena linija razgraničenja Nezavisne Države Hrvatske i Italije, Senj ulazi u sastav NDH i postaje važan politički i administrativni centar. Unatoč uspješnom formiranju raznih političkih i društvenih institucija novoosnovane države, grad nikada nije izrastao u značajno vojno središte Nezavisne Države Hrvatske jer su reokupacijom tzv. Druge talijanske zone u rujnu 1941., u koju je spadao i Senj, talijanske snage osigurale stalnu vojnu prevlast nad gradom. Talijani su Senj pretvorili u važno vojno uporište u kojem se nalazilo zapovjedništvo divizije, opasali ga bodljikavom žicom i zaštitili sustavom brojnih bunkera raspoređenih oko grada, stoga je u ruke Narodnooslobodilačke vojske Jugoslavije prešao predajom talijanske divizije Murge nakon žestokih borbi tek sredinom rujna 1943., i to kao jedna od posljednjih točaka talijanskog otpora na hrvatskoj obali. ${ }^{8}$ Razoružavanjem talijanske vojske u gradu je zatečena velika količina raznovrsnog ratnog materijala kojim je trebalo opskrbiti mnoge postojeće i novoosnovane odrede NOVJ-e. Iz tih razloga, iznimnu važnost stekla je senjska luka koja postaje jedna od najprometnijih i najznačajnijih partizanskih luka, o čemu svjedoči i podatak o osnivanju Drugog pomorskog obalnog sektora sa sjedištem u Senju. ${ }^{9}$

Svjesni tog izrazitog strateškog značaja grada u trenutku naglog rasta partizanske moći, ali i u neprestanom strahu od moguće savezničke invazije s nasuprotne talijanske obale, njemačke snage početkom listopada 1943. pokreću ofenzivu velikih razmjera na oslobođeno područje Gorskog kotara i Hrvatskog primorja. Prodor kopnenih snaga prema Senju zaustavljen je snažnim partizanskim otporom kod Novog Vinodolskog. No, kako su kopnenom prodoru potporu pružale zračne snage, Senj su 7., 8. i 9. listopada 1943. godine žestoko bombardirali zrakoplovi Njemačkog ratnog zrakoplovstva (Luftwaffe). Izgledno je da su im glavni ciljevi bili upravo veći broj trgovačkih i vojnih brodova u senjskoj luci, a kako napad nije bio očekivan, faktor iznenađenja znatno je pridonio njegovom uspjehu. ${ }^{10}$ Među civilnim žrtvama najtragičnijeg

${ }^{8}$ M. SOBOLEVSKI, 2003, 365-366.

${ }^{9}$ M. SOBOLEVSKI, 2003, 368. Opširnije o tome K. PRIBILOVIĆ, 1975, 351-362; A. GIRON, 1984, 319-322.

${ }^{10}$ Usp. A. GLAVIČIĆ, 1984, 368-369; M. SOBOLEVSKI, 2003, 369--372. Iako je o njemačkim bombardiranjima poznato znatno manje podataka nego o savezničkim, pretpostavlja se da su zrakoplovi tipa Junkers Ju-87 ("Štuka") koji su izveli napade na Senj pripadali 151. borbenoj grupi (II./Stg 151) Njemačkog ratnog zrakoplovstva (Luftwaffe) (L. PERŠEN - M. RAGUŽ, 2018, 75). 
bombardiranja koje je Senj doživio za Drugog svjetskog rata, kojim je počinjena nepovratna šteta mnogim značajnim kulturno-povijesnim spomenicima $u$ najstarijoj jezgri grada, novijim istraživanjima poimence je utvrđeno 48 poginulih osoba. ${ }^{11}$ Ovladati senjskim područjem, u čemu tada nisu uspjele, a što je grad platio velikim ljudskim gubicima i značajnom materijalnom štetom, njemačke snage uspjet će početkom naredne godine, u siječnju 1944., kada će zaposjesti grad. Suočeni sa rastućim pritiskom partizanskih i savezničkih napredovanja, Nijemci su grad utvrdili i ojačali nizom fortifikacija koji su trebali grad, a naročito luku, zaštititi od realne opasnosti koja je prijetila iz zaleđa, s mora, te ponajprije, iz zraka u kojem je savezničko zrakoplovstvo već početkom 1944. ostvarilo premoć.

Zbog partizanske blokade kopnenog prometa Senj ponovno dobiva na važnosti kao vojno i pomorsko središte iz kojega se moglo morskim putem djelovati na širi prostor. Iz tog je razloga od njemačkog zaposjedanja pa sve do završnih borbi krajem rata grad bio cilj taktičkih zračnih bombardiranja savezničkog zrakoplovstva, koja su, koliko je to prema dostupnim dokumentima moguće utvrditi, izvršena u 13 navrata u razdoblju od srpnja 1944. do kraja veljače 1945. godine. ${ }^{12}$ Međutim, nedvojbena je činjenica da su ta bombardiranja, znatno učestalija i intenzivnija u odnosu na prethodna njemačka iz listopada 1943. godine, ipak rezultirala razmjerno manjom materijalnom štetom i ljudskim žrtvama. Prema podatcima iz više izvora, poimeničnom identifikacijom utvrđeno je 13 žrtava, što je naspram utvrđenih 48 osoba poginulih u njemačkim

11 Prema sjećanjima građana, uoči bombardiranja njemački je zrakoplov bacao letke propagandnog karaktera. Iz tog razloga, a vjerojatno i zbog partizanskih obavijesti o njemačkom prodoru, veći dio građana je izašao izvan grada. No, usprkos tome, stradao je veliki broj civilnih žrtava te partizanskih boraca i mornara koji su se zatekli u luci. Za dosad utvrđeni popis žrtava usp. M. SOBOLEVSKI, 2003, 360-372; A. GLAVIČIĆ, 1984, 351, bilj. 9.

${ }^{12}$ Pod pojmom "taktička bombardiranja" podrazumijevaju se zračna djelovanja na ciljeve izrazitog prometnog ili gospodarskog značaja u kojima su nositelji misija primarno bile eskadrile srednjih bombardera. Djelovanje po cilju ispuštanjem bombi sa srednjih ili većih visina odlika je takvih misija koje bi valjalo razlikovati od ciljanih napada lovaca i lovaca-bombardera usmjerenih na specifične ciljeve manjeg obima (npr. brodove, topničke položaje ili trupe u pokretu). Prema utvrđenim podatcima, Senj je bio meta taktičkih bombardiranja u 13 navrata (M. SOBOLEVSKI, 2003, 372; M. KARAKAŠ OBRADOV, 2008, 177). Međutim, čini se da ta brojka nije konačna jer se u drugim izvorima pojavljuju još neki datumi (vidi. M. BILOVIĆ et al., 2010, 27). Broj ciljanih napada lovaca i lovaca-bombardera na specifične ciljeve poput brodova u luci nije moguće pouzdano utvrditi, no zasada je sigurno da su u napade tog tipa na ciljeve u Senju svakako bile uključene 16. eskadrila SAAF-a, 19. eskadrila SAAF-a, 39. eskadrila RAF-a, 6. eskadrila RAF-a te 351. i 352. eskadrila RAF-a s partizanskom posadom. Za eskadrile srednjih bombardera koje su izvršile napade na Senj vidi M. BILOVIĆ et al., 2010, 16-25. 
bombardiranjima, ipak razmjerno manja brojka. ${ }^{13} \mathrm{Uz}$ izgrađena skloništa i već stečeno iskustvo Senjana s napadima iz zraka, jedan od glavnih uzroka koji je ponajviše pridonio manjem broju žrtava jest selektivno bombardiranje, odnosno razvidno manja količina bombi koje su pale na središnju gradsku jezgru zgusnutu i prenapučenu mnogobrojnim stambenim objektima na maloj površini. Na takav zaključak upućuje uvid u fotografije zračnih bombardiranja zabilježenih iz savezničkih zrakoplova s položajima detonacija ispuštenih bombi, gdje se uočava tendencija ciljanja luke i skladišnih objekata uz nju smještenih. Takav odabir ciljeva sugerira upravo taj prostor kao stvarni objekt napada, a dodatni prilog tomu su i saveznička izvješća u kojima su kao glavni ciljevi misije navedeni lučki objekti. ${ }^{14}$

Tijekom 1944. i 1945. godine, senjska luka, kao sigurno sklonište za mnoge brodove koji su se zaputili na neizvjesnu i opasnu plovidbu nepredvidivim Senjskim i Podgorskim kanalom, ili kao posljednje odredište većeg broj trgovačkih i vojnih brodova s teretom ratne opreme, hrane i oružje koja se najkraćim kopnenim putem dalje distribuirala u unutrašnjost, bila je od iznimnog vojnog značaja. Stoga, iz perspektive ratnih taktika te prirode savezničke i partizanske suradnje, odluka savezničkog zrakoplovstva o bombardiranju luke, lučkih objekata i skladišta uz nju smještenih, potencirana partizanskim izvještajima, a dijelom uvjetovana i podatcima prikupljenim snimanjima izviđačkih zrakoplova, nije iznenađujuća, tim više što su, uz gospodarske objekte, i vojni brodovi privezani ili usidreni u luci predstavljali legitiman vojni cilj. Međutim, valja naglasiti da taktička bombardiranja nisu bila jedina zračna

13 Komparacijom popisa Hinka Martulaša koji je kronološki zabilježio saveznička bombardiranja te poimenično naveo njihove žrtve (M. BILOVIĆ et al., 2010, 27) te podataka koje u svojem radu iznosi M. Sobolevski (M. SOBOLEVSKI, 2003, 373-375) moguće je utvrditi da je u savezničkim bombardiranjima poginulo najmanje 13 civilnih žrtava, i to: 12. listopada 1944. (Anton Rošić, Marijan Butorac, Marijan Babić, (?) Pilepić, Zvonko Domines), 4. studenog 1944. (Vinko Sečka, "jedan kirac i jedna kirica"), 18. siječnja 1945. (Josipa Vukelić Beba, Ivica Šimunić, Zlata Karadžija) i 20. veljače 1945. (Adela Glavan, Ivica Svast). Popis se zasniva na dosad objavljenim podatcima. Na pitanje koliko je točno ljudi poginulo u savezničkim i njemačkim bombardiranjima Senja nemoguće je dati precizan odgovor. Još uvijek nije poznato koliko je ljudi ranjeno ili koliko ih je poginulo od posljedica ranjavanja, a žrtve bombardiranja su bili i njemački vojnici. Također, vrijedi napomenuti da u ponekim izvorima koji donose broj žrtava nije jasno radi li se o civilnim ili vojnim žrtvama, ili jednima i drugima. Usp. M. SOBOLEVSKI, 2003, 373; M. KARAKAŠ OBRADOV, 2008, 178.

${ }^{14}$ M. BILOVIĆ et al., 2010, 21-26. Zbog specifičnog položaja, luka i grad su jedna usko povezana cjelina, pa se stoga pogodci javnih i stambenih gradskih objekata nisu mogli izbjeći. Zbog sličnih razloga i mnogi drugi gradovi na našoj obali pretrpjeli su velika razaranja u zračnim bombardiranjima tijekom Drugog svjetskog rata. 
djelovanja usmjerena na luku jer su pojedini brodovi koji su se određenom trenutku u njoj zatekli bili ugroženi čestim aktivnostima savezničkih lovaca ili lovaca-bombardera koji su korišteni u napadima na manje, specifične i planirane ciljeve ili su u tzv. patrol sweep misijama letjeli i izviđali duž obale u nasumičnoj potrazi za neprijateljskim brodovima, spremištima goriva, topničkim položajima ili trupama u pokretu. ${ }^{15} \mathrm{U}$ arhivskim dokumentima zabilježen je veći broj napada takvog tipa tijekom 1944. i 1945. godine, ne samo na ciljeve u senjskoj luci, već i na brodove koji su zbog stalne dnevne prijetnje iz zraka potražili sklonište u lukama i zaljevima podvelebitskog kanala, pri čemu je potopljen ili oštećen poveći broj, uglavnom njemačkih desantnih peniša i rekviriranih plovila, ali je oboreno i nekoliko savezničkih zrakoplova. ${ }^{16} \mathrm{U}$ jednoj od takvih ciljanih misija savezničkih zračnih snaga, u listopadu 1944. godine djelovanjem protuzračne obrane s njemačkog broda Arpione privezanog na gat Sv. Nikole u senjskoj luci oboren je lovac-bombarder Bristol Beaufighter koji se srušio u more nekoliko stotina metara ispred luke. ${ }^{17}$

\section{Olupina zrakoplova}

Ostatci srušenog zrakoplova nalaze se oko 200 metara zapadno od vrha gata Sv. Ambroza (Mađarske rive) na dubini od 22 metra (Karta 1.). Okruženi zaostalim ribarskim mrežama i bocama koje prekrivaju pjeskovito dno, u širokom krugu od petnaestak metara razbacani su dijelovi zrakoplova obrasli morskom travom i spužvama. Po njihovoj disperziji i stanju očuvanosti može

${ }^{15}$ M. BILOVIĆ et al., 2010, 18; vidi bilj. 7 u ovome radu.

${ }^{16} \mathrm{U}$ savezničkim izvješćima registrirano je više napada na brodove u senjskoj luci, uvali Spasovac, Sv. Jurju, Lukovu, Zavratnici i drugim uvalama Podvelebitskog kanala. Zrakoplovi koji su najčešće izvodili takve napade uvlačeći se u svaku uvalu (škrapu) Senjani su nazivali "škrapari" (M. BILOVIĆ et al., 2010, 18). Osobito je uzak i dubok zaljev Zavratnice služio njemačkim brodovima kao izvrsno zaklonište od napada savezničkog zrakoplovstva. Istovremeno, konfiguracija uvale bila je otežavajuća okolnost za izvođenje zračnih napada, koji su bili osobito riskantni jer su se zrakoplovi morali zavlačiti u samu uvalu kako bi pogodili zadani cilj. O tim burnim ratnim vremenima obilježenim neprestanom opasnosti iz zraka danas svjedoči olupina njemačke desantne peniše $L F 126$ koja leži u uvali kao jedna od žrtava savezničkog zrakoplovstva. Također, u dva navrata njemačka protuzračna obrana je oborila britanske zrakoplove tipa Hawker Hurricane koji su pripadali 6. eskadrili RAF-a. O olupini broda i srušenim zrakoplovima u uvali Zavratnica vidi D. FRKA - J. MESIĆ, 2012, 154-161.

${ }^{17}$ Prvi spomen srušenog zrakoplova u stručnoj literaturi donosi A. Glavičić u članku Mjesta pogibije i pokapanja vojnika i civila tijekom Drugoga svjetskog rata i poraća na području grada Senja i primorskih obronaka Kapele i Velebita od 1941. do 1946. (III. dio) (A. GLAVIČIĆ, 2001, 230). 


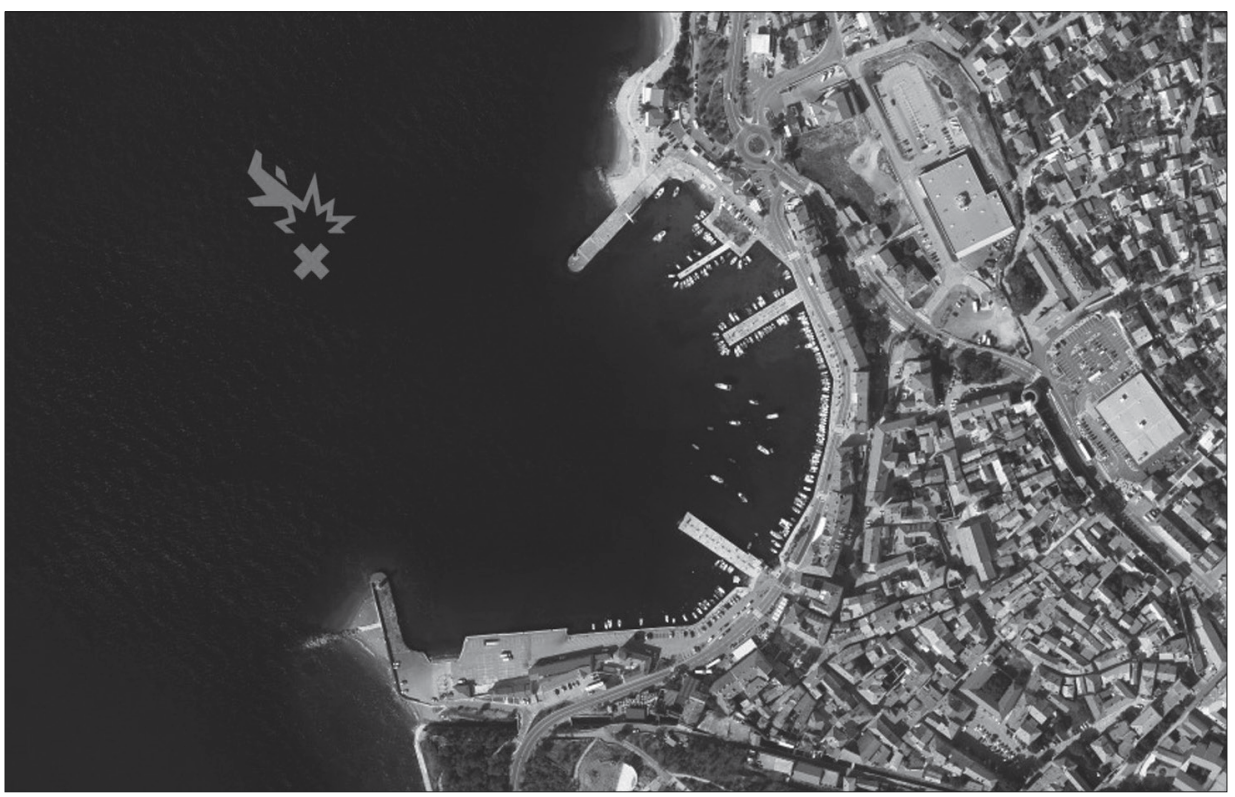

Karta 1. Položaj olupine Bristol Beaufighera NT997 zapadno od gata Sv. Ambroza (izvor: Arkod- http://preglednik.arkod.hr/ARKOD-Web/) (2019-06-29)

se zaključiti da je zrakoplov velikom brzinom udario u morsku površinu te se od siline udarca razbio u masu dijelova koji su se razletjeli po širem prostoru (Sl. 1.). Na dnu se mogu pronaći "zgužvani" komadi oplate i posve deformirani dijelovi zrakoplovne konstrukcije među kojima se pažljivijim pregledom mogu uočiti karakteristični elementi krila i repa (S1. 2.), dijelovi zrakoplova koji su pri udaru s morskom površinom prošli s razmjerno manjim oštećenjima nego prednji dio s nosom i pilotskom kabinom od kojeg je ostala samo masa gotovo neprepoznatljivih dijelova. Pažnju privlači dobro očuvani stražnji dio trupa koji pruža pogled u unutrašnju konstrukciju repa. Dio dijelova od zrakoplovnog lima vjerojatno se neočekivano našao u ribarskim mrežama, a ta aktivnost dijelom je doprinijela stvaranju slike onoga što sada nalazimo na lokaciji pada. ${ }^{18}$ Također, relativno mala dubina dostupna sportskim i rekreativnim roniocima

${ }^{18}$ U dvorištu Gradskog muzeja u Senju već dugo vremena stoji trokrilni propeler na kojem se mogu opaziti još uvijek dobro očuvanom žutom bojom označeni vrhovi. Propeler je otkupljen krajem 1980-tih od ribara koji su ga zahvatili u koćarskoj mreži. Takav tip propelera koristilo je više zrakoplova tijekom Drugog svjetskog rata, a među njima i Bristol Beaufighter. Iako nije poznata točna lokacija pronalaska, a oznake na glavi propelera nisu od pomoći pri povezivanju s olupinom, ne može se isključiti mogućnost da je on ipak pripadao Bristol Beaufighteru NT997. 
pogodovala je odnošenju zanimljivih i privlačnih dijelova među kojima je i dvadesetmilimetarski top Hispano koji je danas izložen kao dio Zbirke oružja $i$ vojne opreme Gradskog muzeja Senj. ${ }^{19} \mathrm{~S}$ istog mjesta potječu strojnica Browning (cal 303.) i još jedan cjelovito očuvan top Hispano $(20 \mathrm{~mm})$ koji se čuvaju u jednoj privatnoj kolekciji. Na kućištu toga Hispana ostao je očuvan bijelom bojom istaknut serijski broj NT997 što će se pokazati osobito važnim podatkom $\mathrm{u}$ identifikaciji olupine. ${ }^{20}$ Zbog okolnosti pada u more i kasnijih aktivnosti na mjestu pada, ne može se isključiti da naslage pjeskovitog dna uokolo olupine i dalje skrivaju druge dijelove srušenog zrakoplova.

\section{Tehničke karakteristike}

Na osnovi izgleda i oblika utvrđenih dijelova zrakoplovne konstrukcije te podataka o izvađenim dijelovima naoružanja, pronađeni ostatci se $\mathrm{s}$ velikom sigurnošću mogu pripisati zrakoplovu tipa Bristol Beaufighter (Sl. 3.). Ovaj višenamjenski dvosjedni zrakoplov britanske proizvodnje razvijen je neposredno prije rata kao odgovor na zahtjev Kraljevskog ratnog zrakoplovstva (RAF) za teško naoružanim dalekometnim lovcem koji bi se temeljio na modelu torpednog bombardera Bristol Beauforta, koji je tek tada ulazio u proizvodnju i uporabu. Međutim, ulaskom u službu 1940. godine Beaufighter, popularno zvan i Beau, pokazao se prikladnim za ulogu noćnog lovca, što je vrhunskim rezultatima i dokazao u presudnoj zračnoj bitci za Britaniju, a tijekom rata službom u sastavu svih savezničkih zračnih snaga njegova prilagodljivost, brzina i vatrena moć pokazat će se ključnim karakteristikama koje će mu omogućiti široku primjenu, od noćnog ili dalekometnog lovca, torpednog

${ }^{19}$ Prema informaciji Vlatka Dominesa Petera (u čijem je posjedu bio Hispano prije no što je doniran Gradskom muzeju Senj), top, kojem nedostaje prednji dio cijevi, izronili su Petar (Marin) Tomljanović i Slavko (Čiko) Šarić početkom 1990-tih na lokaciji pada Beaufightera. (Na informaciji o okolnostima nalaza topa i propelera, kao i na neizmjernoj pomoći i poticaju u pisanju ovog rada posebno zahvaljujem svojeme ocu Vlatku Dominesu Peteru).

${ }^{20}$ Spomenuti Browning i Hispano dio su privatne kolekcije Danijela Frke, poznatog podvodnog istraživača i povjesničara. Prema njegovim riječima, top Hispano je pronađen dijelom ukopan u pijesak koji je očuvao zanimljiv natpis na njegovom kućištu. Bijelom bojom ručno je bio ispisan serijski broj zrakoplova NT997 i oznaka P.O. (Port Outer - lijevi, vanjski). Na taj način označeno je na kojem položaju na trupu je top bio instaliran kako bi poslije redovitog demontiranja radi čišćenja bio ponovno postavljen na originalno mjesto. Time je sa sigurnošću potvrđena identifikacija ostataka kao dijelova Bristol Beaufightera NT997. (Na mnoštvu korisnih informacija i vrijednih zapažanja o ostatcima zrakoplova te ustupljenim fotografijama za objavu zahvaljujem Danijelu Frki). 


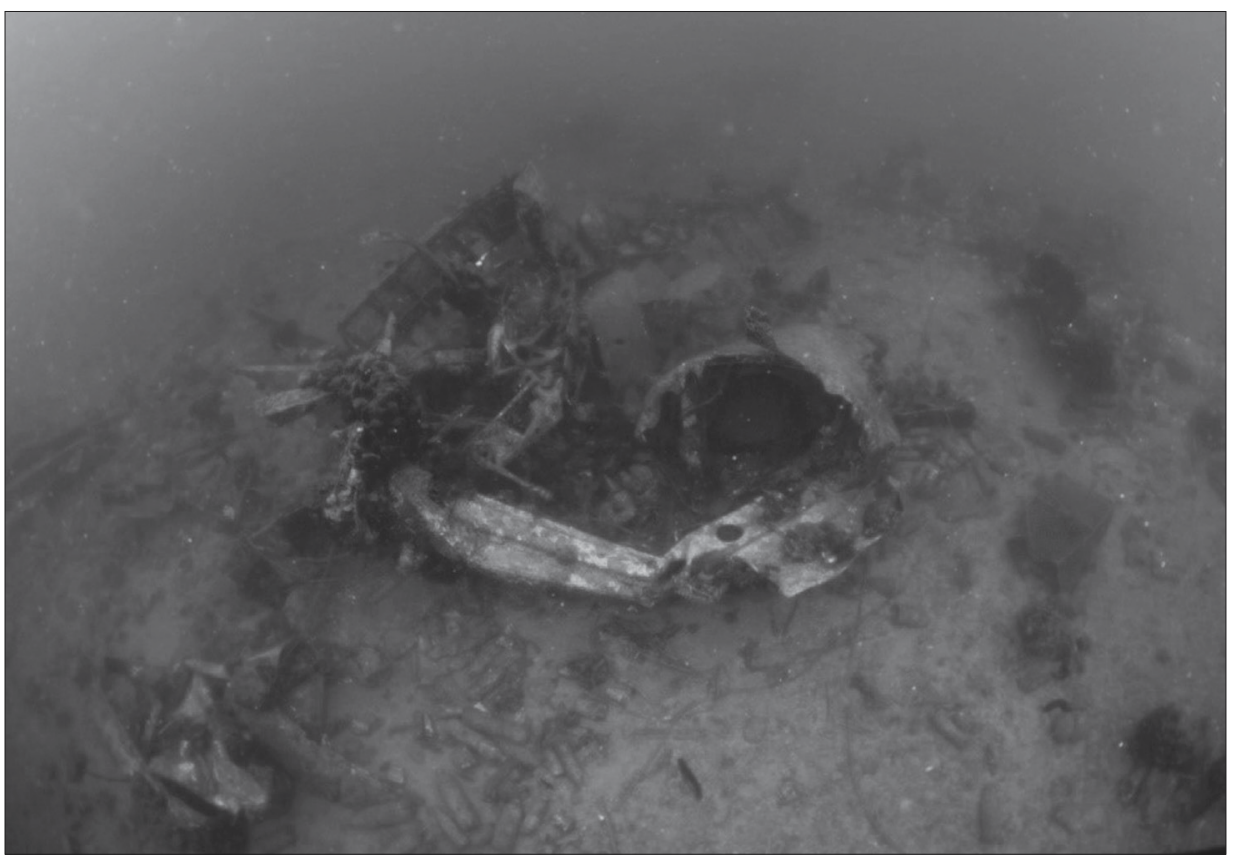

S1. 1. Dijelovi zrakoplova raspršeni po dnu (foto: Danijel Frka)

ili srednjeg bombardera do izviđačkog zrakoplova, a ujedno i potaknuti proizvodnju različitih tipova i varijanti.

U najvećem broju je proizveden tip TF Mk X (Torpedo Fighter Mark X) koji se pokazao osobito efikasnim u napadima na njemačke i talijanske brodove. S duljinom 12.6 metara i rasponom krila $17.6 \mathrm{~m}$ Beaufighter je bio opremljen dvama četverocilindričnim motorima Bristol Hercules jačine 1600 konjskih snaga koji su pružali maksimalnu brzinu od $515 \mathrm{~km} / \mathrm{h}$. Posadu zrakoplova su činila dva člana: pilot koji je njime upravljao i navigator (ili Observer) na položaju repnog strijelca. Njegova vatrena moć se temeljila na četiri Hispano Mk. III topa kalibra $20 \mathrm{~mm}$ smještena u donjem dijelu trupa i više strojnica tipa Browning (cal $.303 ; 7.7 \mathrm{~mm}$ ) instaliranih u krilima i na položaju repnog strijelca, a po potrebi i karakteru misije mogao je ponijeti i širi izbor bombi različitih masa, britanski 18-inčni torpedo ili osam RP-3 $60 \mathrm{lb}(27 \mathrm{~kg})$ ili $25 \mathrm{lb}(11.3 \mathrm{~kg})$ raketa, poglavito namijenjenih probijanju oklopnih meta. ${ }^{21}$ Posebna karakteristika bila je visoko rezolucijska kamera smještena u nosu zrakoplova koja bi automatski snimala

${ }^{21}$ P. J. R. MOYES, 1966, 3-16; L. BRIDGEMAN, 1946, 110-111. 
fotografije po otvaranju vatre iz topova ili aktivacijom prekidača za lansiranje raketa. Na taj način zabilježene su izvanredne fotografije zračnih napada na neke od ciljeva i na području današnje Hrvatske. ${ }^{22}$

\section{Usmeno svjedočanstvo o padu zrakoplova}

Gusti dim koji uz zvuk tutnjave motora prati trag gorućeg zrakoplova koji se u strmoglavoj putanji obrušava u more dojmljiv i upečatljiv je prizor na nebeskom svodu koji se svjedocima snažno urezuje u pamćenje.

Unatoč tome, danas - 75 godina od toga događaja, odmak vremena učinio je svoje i oteo priliku ili prepustio zaboravu mnoge korisne podatke iz dragocjenih svjedočanstava osoba koje su proživjele i preživjele to razdoblje senjske povijesti. Stoga je potraga za starijim Senjanima bistrog pamćenja, koji su svjedočili obaranju zrakoplova i toga se dobro prisjećaju, teža zadaća no što se naizgled čini, što i svaku dobivenu informaciju iz osobnih sjećanja čini vrjednijom i dragocjenijom. No, sav uloženi napor isplatio se u razgovoru s g. Ladislavom Gržinom (r. 1932.), čije su djetinjstvo obilježile burne i teške ratne okolnosti. ${ }^{23}$ Razborit i dobrog pamćenja, još uvijek se dobro sjeća mnogih događaja iz tog nemilog razdoblja pa tako i dana kada je srušen predmetni zrakoplov. Prema njegovom sjećanju "to je bil deseti misec 44-e", a cilj napada je bio "brod Arpione" koji je bio privezan u luci. Kazao je da je napadu svjedočio "oko 3 ure popodne", na putu prema skloništima na "Krivoputskoj cesti" dok je "išal starome (koji je radio na gradnji zračnih skloništa u predgrađu Senja) nosit marendu". Mirno jesensko popodne prekinuo je gromovit zvuk britanskih zrakoplova, a sirena za zračnu uzbunu nagovijestila je zračni napad. Njemački topovi otvorili su na zrakoplove vatru sa svih strana, zamela se prava borba, a "iz repa se dim pokazal k'o magla". Prema njegovim riječima, zrakoplov je padao "sve niže i niže" te "kod Škvera ode u more", jedno "četiristo metri od ferala Mađarske rive". Osim podataka povezanih uz pad zrakoplova, g. Gržin sjeća se još mnogih događaja iz tih ratnih godina, a dobro mu je poznat i kontekst savezničkih bombardiranja: "preko Senja letile su eskadrile, to su bile one tvrđave, zemlja bi tutnila, pesak bi podhrtaval ... oni su imali one lovce ki su ti njih obezbeđivali".

U cjelini gledajući, usmena kazivanja od iznimne su koristi u istraživanjima srušenih zrakoplova jer mogu pružiti dragocjene podatke o

${ }^{22}$ S. STEVENS, 2006, 83.

${ }^{23}$ Razgovor s g. Ladislavom Gržinom odvijao se u njegovoj kući u Senju, 2. travnja 2019. Zahvaljujem mu na susretljivosti i volji da iznese svoja sjećanja. 


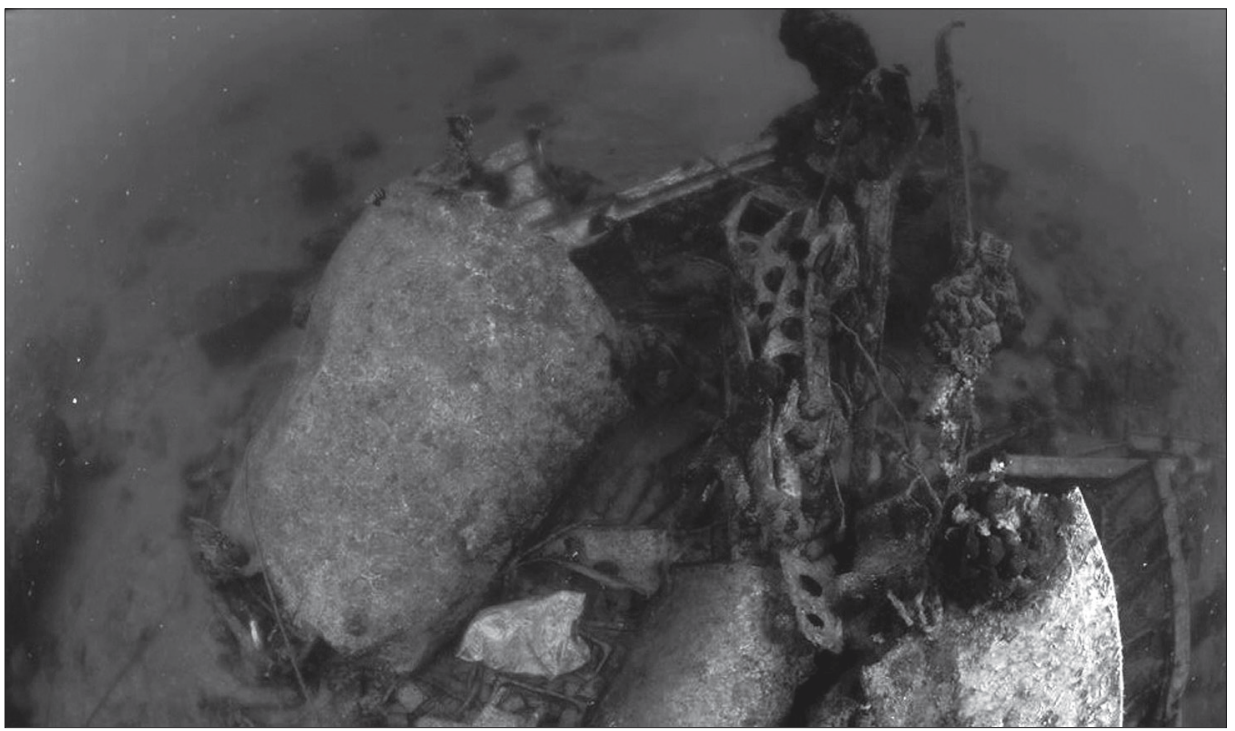

Sl. 2. Ostatci zrakoplova s dijelovima repa u prvom planu (foto: Danijel Frka)

okolnostima i okvirnom vremenu pada, što znatno olakšava daljnji postupak identifikacije zrakoplova komparacijom prikupljenih spoznaja sa pronađenim arhivskim dokumentima. U tom smislu, i informacije iz kazivanja g. Gržina omogućile su povezivanje osobnog svjedočanstva s ustanovljenim povijesnim činjenicama.

Identifikacija zrakoplova, rekonstrukcija tijeka misije $i$ rasvjetljivanje okolnosti pada

Uz informacije o tipu zrakoplova, okolnostima napada, okvirnom vremenu i mjestu pada prikupljenim pregledom olupine i usmenim kazivanjem svjedoka toga događaja, ključni faktor za sigurnu identifikaciju olupine predstavlja oznaka NT997 na kućištu jednog od pronađenih topova. Uvažavajući sve navedene podatke i analizirajući prikupljena vojna izvješća, može se zaključiti da ostatci zrakoplova srušenog u more nedaleko gata Sv. Ambroza u Senju bez ikakve sumnje pripadaju zrakoplovu Bristol Beaufighter $M k X$, serijskog broja NT997 koji je srušen 10. listopada 1944. godine djelovanjem protuzračnog topništva prilikom napada na neprijateljski brod u senjskoj luci.

Podatci o izgubljenom zrakoplovu koji se poklapaju s tipom zrakoplova, lokacijom, vremenom i utvrđenim okolnostima pada zabilježeni su na Izvješću 
o borbenom letu 10. listopada 1944. (Sortie Report No. 43146). ${ }^{24}$ Sortie Report je izvješće o poduzetim borbenim letovima koji navodi cilj misije, pruža uvid u broj zrakoplova i pilota koji su sudjelovali u borbenom letu, donosi podatak o eskadrili koja je bila nositelj operacije, matičnom uzletištu, vremenskim prilikama koje su vladale toga dana te opis tijeka misije od trenutka polijetanja formacije zrakoplova uključenih u operaciju do povratka u zračnu bazu. Uvidom u sadržaj izvješća može se saznati da je: " Sa zadaćom napada na transportni brod za kojeg su postojale indicije da bi se mogao nalaziti u luci Novog Vinodolskog ili Senja, iz zračne luke Biferno u južnoj Italiji 10. listopada 1944. u otprilike 13.20 sati poletjelo je deset Bristol Beaufightera označenih kodnim slovima Y, J, U, S, X, Q, A, C, D i F kojima su upravljali piloti 19. eskadrile Južnoafričkog ratnog zrakoplovstva (No. 19 Squadron SAAF)". Međutim, nedugo nakon polijetanja, zbog problema s motorom, Beaufighter kodnog slova "F" prisilno se vratio u bazu. Ostalih devet zrakoplova nastavilo je put prema luci Novog Vinodolskog. Vidljivost u duljini od 18 milja otežavali su niski, slojeviti oblaci i nadolazeći olujni oblaci koji su prijetili sa sjeverozapada. Prilaskom luci Novog Vinodolskog, u njoj nije uočen traženi brod, već samo manji drveni brod kojeg je topovskom vatrom napao vođa formacije (Y). Stoga, u potrazi za ciljem, formacija je nastavila let deset milja prema sjeveru, a potom se zaokrenula u smjeru istočne obale otoka Krka. Letom uz obalu Krka zamijećena su dva manja drvena broda u uvali južno od Vrbnika na koje je također otvorena vatra, a prilaskom senjskoj luci oko 15 sati uočen je i glavni cilj misije, brod privezan na južnoj strani središnjeg gata okrenut prema obali. Brod je napadnut u nekoliko valova: prvi je topovskom vatrom i lansiranjem osam raketa $(25 \mathrm{lb})$, od kojih su četiri pogodile brod, napao vođa formacije ("Y"), a potom su zajedničkom topovskom vatrom i raketama napali "O" i "A" zrakoplovi, nanijevši direktnim pogodcima štetu na brodu, za kojeg "se činilo da je u plamenu". Pri tom napadu oboren je Beaufighter "A" koji se srušio u more u luci. Njime je upravljao F/ Lt. (Flight Lieutenant) Vance, dok je Lt. (Lieutenant) Medalie bio na položaju promatrača (repnog strijelca). Prilikom sljedećeg vala napada u glavu je teško ranjen Sgt. (Sergeant) Quick koji je bio promatrač na zrakoplovu "C" kojim je upravljao Lt. Franken. Ostali zrakoplovi nisu mogli doći u poziciju za napad raketama, stoga su višestruko napali topovskom vatrom. "D" zrakoplov nije

${ }^{24}$ Izvješće o borbenom letu 10.10.1944. (Sortie Report No. 43146) (http://www. nationalarchives.gov.uk) (2019-11-14). Na iskazanoj pomoći u potrazi Izvješća, kao i na mnogim korisnim savjetima i sugestijama, zahvaljujem Radovanu Živanoviću, neumornom istraživaču olupina srušenih zrakoplova i vrsnom poznavatelju naše zrakoplovne prošlosti iz razdoblja Drugog svjetskog rata. 


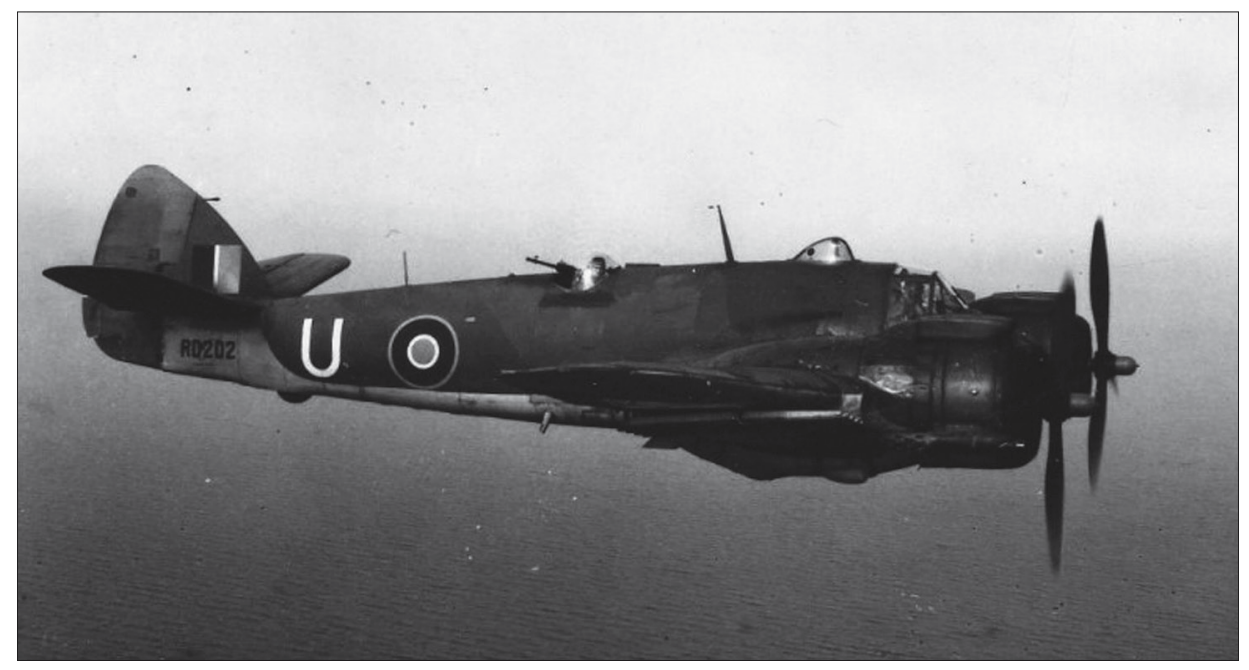

S1. 3. Jedan od Bristol Beaufightera $M k X$ iz sastava 19. eskadrile SAAF-a (izvor: http://saafww2pilots.yolasite.com/paul-kruger.php) (2019-05-12)

sudjelovao u napadima. U polazišnu zračnu luku Biferno formacija se vratila u 16.40 sati. Zacrtani cilj operacije tek je djelomično postignut, brod je pogođen i ostavljen u požaru, a oštećena i zapaljena su tri manja drvena broda. S druge strane, izgubljen je jedan Beaufighter s dva člana posade, dok je jedan pilot teško ranjen u glavu." 25

Pri utvrđivanju okolnosti napada i pada zrakoplova, identifikaciji glavnog cilja napada te traženju informacija o sudbinama članova posade od velike su koristi bili drugi pronađeni arhivski dokumenti koji su izravno povezani s padom zrakoplova. U prvom redu, to je Izvješće o okolnostima gubitka (Circumstantial Loss Report) u kojem su zapisane okolnosti stradavanja jednog od dva člana

25 Izvješće o borbenom letu 10.10.1944. (Sortie Report No. 43146) (http://www. nationalarchives.gov.uk) (2019-11-14). U misiji su sudjelovali Maj. Geere - Lt. Ironside (Y). Lt. Dickson - F/O Brace (J), F/S Abbott - F/Lt. Buxton (U), Lt. Henry - F/O Thomas (S), F/Lt. Snape - F/S Smith (X), W/O Davis - F/S Sefton (Q), F/Lt. Vance - Lt. Medalie (A), Lt. Franken - Sgt. Quick (C), F/S Sheldrick - F/S Ash (D). F/S Smith - F/S Johnson (F) vratili su se u bazu nedugo nakon polijetanja. O daljnjoj sudbini narednika Quicka nisu nađeni podatci u arhivskim spisima. Potraga za još uvijek živim sudionikom te operacije također nije bila uspješna. Uvidom u popis poginulih pripadnika 19. eskadrile došlo se do podataka da su Lt. Henry i F/O. Thomas poginuli 31.10.1944. na zadatku napada brodova u Biokovskom kanalu, dok su Lt. Dickson i F/O. Brace poginuli 20.3.1945. u operaciji kojoj je cilj bio raketiranje njemačkog zapovjedništva u dvorcu Cernik. Informacije o sudbinama drugih sudionika napada i njihovim ratnim i životnim putevima nisu pronađene. 
posade, poručnika Alexandra Morrisa Medalieja. ${ }^{26}$ U izvješću stoji: "da je 23-godišnji Lt. Medalie poginuo 10. listopada 1944. oko 15 sati kada je njegov zrakoplov, Bristol Beaufighter Mk X, serijskog broja NT997, identifikacijskog slova "A" kojim je upravljao F/Lt. A. R. Vance pogođen protuzračnom vatrom otvorenom s položaja Flak $^{27}$ topa instaliranog na krmi njemačkog broda Arpione u senjskoj luci. Zrakoplov se zapalio i srušio u more neposredno ispred luke. Tijela stradalih nisu pronađena." 28 Dakle, djelovanjem protuzračne obrane s njemačkog broda Arpione koji se nalazio u senjskoj luci oboren je zrakoplov pri čemu su poginula oba člana posade. ${ }^{29}$ Taj pisani trag potvrđuje i usmeno svjedočanstvo o događajima toga dana.

O padu zrakoplova 10. listopada 1944. godine, osim savezničkih izvješća, gotovo pa i nema spomena u drugim izvorima, posebice arhivskoj građi vlasti Nezavisne Države Hrvatske i dostupnim njemačkim dokumentima. Tek uzgredno je podatak o srušenom zrakoplovu spomenut u članku o angloameričkim bombardiranjima Senja objavljenom u zagrebačkom dnevnom listu Nova Hrvatska pod naslovom "Prigodom terorističkog napadaja na Senj teško oštećena zgrada biskupije". ${ }^{30}$ Izneseni podatci o broju pogođenih zrakoplova ne slažu se s utvrđenim činjenicama pa je izglednije da je to preuveličavanje više konstrukcija

${ }^{26}$ Izvješće o okolnostima gubitka (Circumstantial Loss Report) $581438 \mathrm{~V}$ Lt. Alexander Morris Medalie No. 19 Squadron SAAF. Na ustupljenoj preslici Izvješća o okolnostima gubitka, uz dragocjene podatke o Lt. Medalieju zahvaljujem Grahamu Du Toitu, koji je istražio vojni arhiv Documentation Centre South African National Defence Force u Pretoriji. Posredno upućujem zahvale i Thomasu Minnaaru.

${ }^{27}$ Flak je skraćenica od Flakvierling, a odnosi se na vrlo efikasni njemački protuzrakoplovni top, izravni "krivac" za pad mnogih savezničkih zrakoplova tijekom Drugog svjetskog rata.

${ }^{28}$ Izvješće o okolnostima gubitka (Circumstantial Loss Report) $581438 \mathrm{~V} \mathrm{Lt}$. Alexander Morris Medalie No. 19 Squadron SAAF

${ }^{29}$ Ključno pitanje položaja s kojeg je protuzračnom vatrom oboren zrakoplov može se smatrati definiranim. Iako je u monografiji Senj-stradanja u Drugom svjetskom ratu (M. BILOVIĆ et al., 2010, 18.) ostavljena mogućnost da je uzrok pada zrakoplova bilo djelovanje protuzračnog topništva s Nehaja, Izvješće o okolnostima gubitka (Circumstantial Loss Report) otklanja postojeće dvojbe i izravno ukazuje da je predmetni Beaufighter oboren snažnom i preciznom protuzračnom vatrom otvorenom s njemačkog broda Arpione, čemu djelomično u prilog ide i položaj dvocijevnog Flak topa na krmi broda (vidi dalje u radu). U tom kontekstu, za neke buduće rasprave vrijedi napomenuti da topnički položaji raspoređeni na Nehaju nisu bili u funkciji protuzračne obrane već obalnog topništva (Küstenartillerie).

30 "Senj, 18. listopada. - Neprijateljski zrakoplovi napali su 10. o. mj. Senj bombama i strojničkom vatrom. Bombe su pale isključivo na zgradu biskupije, koja je teško oštećena. (...) Prigodom ovog napada srušena su dva zrakoplova, koja su pala u more. Pogođen je i treći, te se pretpostavlja, da je i on srušen. Jedan srušeni zrakoplov potonuo je u samoj luci. Od posade nije nitko spašen. (...)" (M. SOBOLEVSKI, 2003, 373). 
promidžbene politike nego odraz istinitih događaja. Informacija koja govori da članovi posade nisu spašeni, koju bi se moglo povezati uz pad predmetnog zrakoplova, podudara se s već poznatim navodom iz Izvješća o okolnostima gubitka, pa se stoga može i uvjetno prihvatiti kao njegova potvrda. Također, podatak o padu savezničkog "lovca" 10. listopada 1944. zabilježen je na popisu zračnih napada na grad Senj kojeg je za vrijeme rata napravio Senjanin Hinko Martulaš i koji predstavlja vrijedan i autentičan izvor za utvrđivanje kronologije i broja žrtava zračnih bombardiranja Senja u Drugom svjetskom ratu. ${ }^{31}$

\section{Kratka povijest 19. eskadrile SAAF-a i ratni putevi članova posade}

Tragičnu sudbinu zrakoplova dijelila su i dva člana njegove posade. To su bili F/Lt. Alan Russell Vance koji je upravljao zrakoplovom te Lt. Alexander Morris Medalie u ulozi navigatora (promatrača) na položaju repnog strijelca naoružan strojnicom Browning s zadaćom pružanja zaštite od mogućeg napada s leđa. Gubitak poručnika Medalieja i Vance bila je tužna vijest za njihove kolege, suborce i prijatelje u 19. eskadrili SAAF-a o čemu najzornije svjedoči rečenica zapisana u dnevniku eskadrile "It was indeed a sad day when F/Lt. Vance and his navigator failed to return from the operation". ${ }^{32}$ Nositelji operacije tog burnog listopadskog utorka bili su pripadnici 19. eskadrile Južnoafričkog ratnog zrakoplovstva koja je osnovana 12. kolovoza 1944. reorganizacijom 227. eskadrile RAF-a. Iako su pri organizaciji nove jedinice većinu dotadašnjeg RAF-ovog osoblja zamijenili Južnoafrikanci, dio "starih" pripadnika, među kojima je bio i F/Lt. Vance, priključen je novoformiranoj eskadrili. Stacionirana u zračnoj bazi Biferno (Termoli) u talijanskoj regiji Molise i opremljena britanskim zrakoplovima tipa Bristol Beaufighter MkX, postrojba je primarno napadala ciljeve na području Jugoslavije oslanjajući se na informacije koje su dostavljale partizanske snage. Sve do njenog rasformiranja u srpnju 1945. godine, zajedno s 16. eskadrilom SAAF-a, ona je bila integralni dio Balkanskih zračnih snaga (Balkan Air Force) osnovanih u lipnju 1944. s ciljem djelovanja na širem području Balkana uz pružanje zračne potpore partizanskom pokretu. ${ }^{33}$ Podatci o pripadajućoj eskadrili bili su temeljno polazište u potrazi za detaljnijim informacijama o životnim i ratnim putovima poginulih članova posade.

${ }^{31}$ M. BILOVIĆ et al., 2010, 27.

${ }^{32}$ Dnevnik 19. eskadrile SAAF-a, listopad 1944.g. (Na pruženom uvidu u presliku dnevnika i ustupljenoj fotografiji napada 14.8.1944. zahvaljujem Tinusu Le Rouxu).

${ }^{33}$ S. STEVENS, 2006, 79-83; M. BILOVIĆ et al., 2010, 15; http://www.saairforce.co.za/ the-airforce/squadrons/100/19-squadron (2019-02-22). 


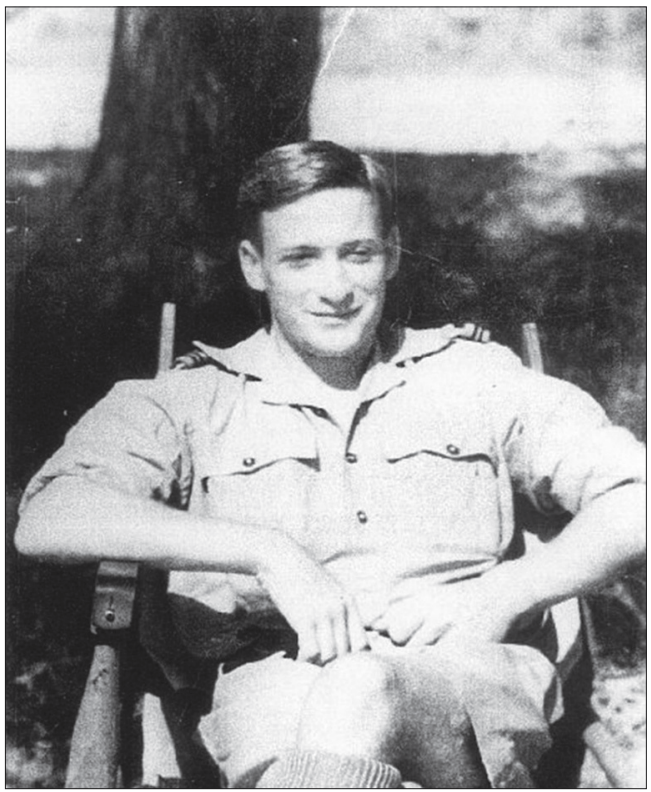

S1. 4. F/Lt. Alan Russell Vance

(izvor: https://sites.google.com/site/ famhistory001/home/arvance) (2019-02-18)

Alan Russell Vance (Service number J/23617) rođen je 11. rujna 1923. u malom mjestu Spanish na obali jezera Huron u južnom dijelu kanadske provincije Ontario (S1. 4.). U svojem rodnom mjestu je pohađao osnovnu i srednju školu, a poslije toga upisao je zrakoplovnu školu Kraljevskog kanadskog ratnog zrakoplovstva (Royal Canadian Air Force) u North Bayu te prošao pilotsku obuku u Brandonu, Torontu, Goderichu i Hagersvilleu. Nakon što je uspješno savladao osnovnu obuku, upućen je u zrakoplovnu školu na Prince Edward Island na dodatne treninge, a stekavši sva potrebna znanja, dodijeljen mu je čin poručnika. U svibnju 1943. poslan je na ratište gdje je prvo kao pripadnik 227. eskadrile RAF-a, a poslije toga 19. eskadrile SAAF-a, sudjelovao u operacijama u Africi, Italiji i Balkanu. Iskazao se mnogim učinkovitim napadima na neprijateljske brodove i naftna postrojenja. Zbog svog izvanrednog noćnog vida koji mu je bio od velike pomoći u noćnim operacijama na neprijateljske ciljeve u Egejskom moru, u 227. eskadrili RAF-a bio je poznat pod nadimkom "Cat's Eye Vance". ${ }^{34}$ U rujnu 1944. prilikom napada na neprijateljski vlak njegov je zrakoplov pogođen protuzračnom vatrom. Unatoč nemaloj šteti na zrakoplovu, poručnik Vance nastavio je let i sigurno doveo zrakoplov do matične baze. Nedugo poslije toga, za vrijeme zadatka 10. listopada 1944. sreća mu je okrenula leđa. Za iskazanu hrabrost i učinkovitost tijekom službe u Kraljevskom kanadskom ratnom zrakoplovstvu, posthumno je primio nekoliko odlikovanja RCAF-a, a jedno od kanadskih jezera nazvano je "Vance" njemu u čast. ${ }^{35}$

${ }^{34}$ Dnevnik 19. eskadrile SAAF-a, listopad 1944.

35 https://sites.google.com/site/famhistory001/home/arvance (2019-02-15). Zahvaljujući neograničenim mogućnostima korištenja interneta i društvenih mreža, uspjelo se stupiti u kontakt s članovima obitelji poginulog poručnika Vancea. Na svoj iskazanoj dobroti i susretljivosti zahvaljujem Diani Bacon iz Spanisha u Ontariju i drugoj rodbini poginulog pilota. 
Njegov kopilot i suborac, poručnik Alec Medalie (Service number 581438V) dijelio je sličan ratni put. Punim imenom Alexander Morris Medalie rođen je u Johannesburgu 17. travnja 1921., a potjecaoje izugledne židovske obitelji iz Bethala u istočnom Transvaalu (Sl. 5.). Pohađao je srednju školu King Edward VII u Johannesburgu, a nakon što je maturirao, odlučio se za studij arhitekture na Wits University $\mathrm{u}$ istom gradu, gdje je kao izrazito likovno nadaren student uspješno diplomirao 1942. godine. Godinu dana poslije, 15. ožujka 1943., slijedeći mnoge svoje sunarodnjake i vršnjake, dobrovoljno se prijavio u službu Južnoafričkog ratnog zrakoplovstva (SAAF). Poslije dva mjeseca, prošavši osnovnu obuku za promatrača i navigatora, prebačen je u 48. zrakoplovnu školu u Woodbrooku

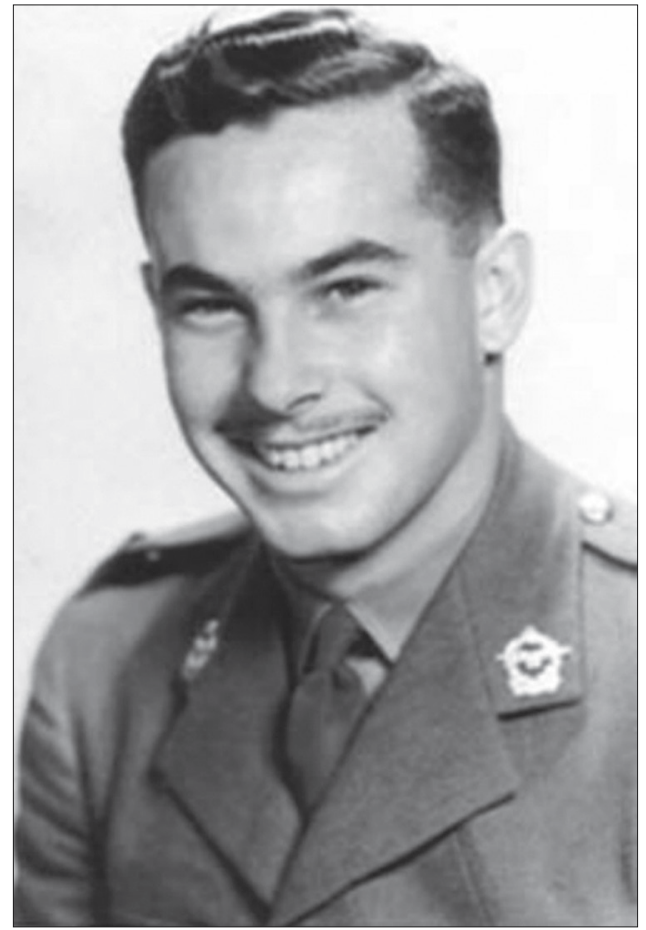

Sl. 5. Lt. Alexander Morris Medalie (izvor: obiteljsko vlasništvo, David Medalie) $\mathrm{u}$ East Londonu, a potom u 66 . zrakoplovnu školu u Youngsfieldu u Capetownu kako bi dovršio naprednu obuku za navigatora. Medalie se uspješno kvalificirao za zračnog promatrača (Flight Observer) u SAAF-u te mu je 26. veljače 1944. dodijeljen čin drugog poručnika (Second Lieutenant). Ubrzo nakon toga, premješten je na Bliski istok, u 70. Jedinicu za operativno osposobljavanje (70 Operation training unit) Kraljevskog ratnog zrakoplovstva (RAF) u Kairu kako bi stekao dodatna praktična znanja prije upućivanja u operativnu eskadrilu. Završivši operativni trening, 27. travnja 1944. prebačen je u 16. eskadrilu SAAF-a, u čijem je sastavu borbeno djelovao i na ciljeve na području Hrvatske sve dok 31. kolovoza 1944. nije premješten u svoju posljednju postrojbu, 19. eskadrilu SAAF-a, kojoj je pripadao sve do pogibije. Za doprinos u Drugom svjetskom ratu posthumno je odlikovan s nekoliko medalja. ${ }^{36}$

${ }^{36}$ Military Service Record, 581438V, Lieutenant (Observer) Alexander Morris Medalie No. 19 Squadron SAAF (zahvaljujući Grahamu Du Toitu). Pomoću pribavljenih podataka, pronađena je i rodbina poručnika Medalieja. David Medalie, profesor na Odjelu za engleski jezik na Sveučilištu 


\section{Poslijeratna potraga za posmrtnim ostatcima}

Budući da izvješća navode da tijela poginulih pilota nisu pronađena neposredno po padu zrakoplova, a tim više što nisu postojali nikakvi podatci koji su izazvali sumnju u istinitost tih navoda, nekoliko godina poslije završetka rata pokrenuto je pitanje pronalaska tijela koje je spadalo u djelokrug Jedinice za istraživanje i potragu za nestalima (Missing research and Enquiry Unit) RAF-a osnovane 1944. godine s ciljem potrage za više od 42000 pripadnika Kraljevskog ratnog zrakoplovstva označenih nestalim ili s pretpostavkom smrtnog stradavanja. Podatak o toj inicijativi u slučaju pada Bristol Beaufightera NT997 ostao je sačuvan u korespondenciji 5. Jedinice za istraživanje i potragu za nestalima (No. 5 Missing \& Research Enquiry Unit) iz ožujka 1948. godine, u kojem je, uz kratak opis misije, donijeto dragocjeno svjedočanstvo Milana Tomljanovića, službenika iz Senja, svjedoka pada zrakoplova, kojeg je pronašao jedan od suradnika jedinice. ${ }^{37}$ Prema sjećanju svjedoka, 10. ili 11. listopada 1944. dvomotorni zrakoplovi napali su njemački brod Arpione u senjskoj luci, a jedan od njih je prilikom napada pogođen, pri čemu se zapalio i srušio u more. Sljedeći dan izronio je mali žuti čamac za spašavanje kojeg su odnijeli njemački vojnici. Također, u tom iskazu, Tomljanović je spomenuo da se za mirnog i bistrog mora može vidjeti olupina na dnu. ${ }^{38} \mathrm{~K}$ tome, u dokumentu je spomenut prijedlog koji je upućen jugoslavenskim vlastima o potrazi za tijelima za kojih se vjerovalo da se još uvijek kriju u olupini. Nažalost, zaključeno je i da nikakva akcija oko toga nije poduzeta te se predlaže da bi slučaj trebao biti zatvoren, a konačna odluka ostavljena je nadležnim vojnim institucijama. ${ }^{39}$

Iako je daljnji razvoj situacije nepoznat, uistinu je teško i pretpostaviti da bi takva potraga za tijelima urodila rezultatima s obzirom na stanje očuvanosti olupine i okolnosti pada prilikom kojeg se zrakoplov u potpunosti raspao. Međutim, usprkos tome, valja napomenuti da nije nemoguće da se posmrtni

u Pretoriji njegov je nećak koji je omogućio fotografiju poručnika Medalieja i pomogao nizom korisnih informacija. Također, zahvale bih uputio i g. Rhodi Berman, rođakinji poginulog pilota na želji da podijeli osobna sjećanja o njegovom životu, obitelji i pogibiji. Posebno mi je drago da su obitelji poginulih pilota uz pomoć ovog istraživanja dobili odgovore na neka dugo otvorena pitanja poput točnog mjesta pada, izgleda olupine te šire slike okolnosti pogibije njihovih predaka o kojima nikada nisu dobili cjelovite informacije.

${ }^{37}$ Korespondencija No. 5 Missing \& Research Enquiry Unit, 23. ožujka 1948. (Presliku pisma i drugih dokumenata vezanih uz poručnika Vancea, koji se čuvaju u Library and Archives Canada omogućio je Joe Fukuto, na čemu mu zahvaljujem).

${ }^{38}$ Korespondencija No. 5 Missing \& Research Enquiry Unit, 23. ožujka 1948.

${ }^{39}$ Korespondencija No. 5 Missing \& Research Enquiry Unit, 23. ožujka 1948. 
ostatci poginulih članova posade i dalje nalaze u naslagama pjeskovitog dna oko olupine. Imajući na umu recentne primjere uspješne potrage za takvim ostatcima u podmorju hrvatskog Jadrana, takva situacija, uostalom, ne bi bila iznenađujuća. ${ }^{40}$

\section{Senj i Arpione u napadima 19. eskadrile SAAF-a}

Pripadnici 19. eskadrile SAAF-a izveli su niz uspješnih zračnih napada na širok spektar različitih ciljeva na području Jugoslavije, poput neprijateljskih brodova, tvornica, željeznica, topničkih položaja, skladišta goriva, industrijskih postrojenja ili trupa u pokretu, o kojima su im informacije najčešće dostavljali partizani. Međutim, cijena intenziteta obavljenih operacija bio je gubitak čak 11 zrakoplova koji su se srušili na lokacijama diljem Jugoslavije, najčešće oboreni djelovanjem protuzračne obrane.$^{41} \mathrm{U}$ tom zbroju, ustanovljenim pregledom gubitaka eskadrile, gotovo je nevjerojatna činjenica da su čak dva zrakoplova tipa Bristol Beaufighter 19. eskadrile SAAF-a izgubljena pri napadima na ciljeve u senjskoj luci. Uz zrakoplov koji je predmet ovog rada, drugi slučaj predstavlja također Bristol Beaufighter, kodnog slova "J" koji je 14. kolovoza 1944. prilikom napada na neprijateljski brod u senjskoj luci pogođen protuzračnom vatrom u lijevi hladnjak ulja te je prinudno sletio na posve mirno more otprilike 2 milje istočno od obale otoka Prvića. Dva člana posade, W/C (Wing Commander) Blackburn i F/Sgt. (Flight Sergeant) Boffin preživjeli su obaranje te su zarobljeni nakon što su se ukrcali u gumenu splav. ${ }^{42}$ Izgledno je da je taj napad bio jedna od prvih misija, a ujedno i prvih gubitaka eskadrile, i to svega dva dana nakon njezina formiranja.

${ }^{40}$ https://www.jutarnji.hr/vijesti/hrvatska/misteriozna-smrt-u-dubinama-dnk-analiza-otkrilakome-pripadaju-kosti-nadene-kod-otoka-visa/7144983/ (2019-02-20). Ako bi se ikad krenulo u potragu za posmrtnim ostatcima poginulih pilota, što bi svakako bila hvalevrijedna inicijativa, arheološki pristup čini se kao jedini djelotvorni put koji bi mogao dovesti do traženih rezultata.

${ }^{41}$ Podatak ustupio R. Živanović.

${ }^{42}$ Izvješće o borbenom letu 14.8.1944. (Sortie Report No. 43201); Četiri Beaufightera iz sastava 19. eskadrile SAAF-a u toj su misiji bili podrška Beaufighterima iz 39. eskadrile RAF-a. Zanimljivo je da je napad savezničkih "lovaca-bombardera (u tekstu označeni nazivom Jabo njemačka skraćena za Jagdbomber - lovac-bombarder ) 14. kolovoza 1944. spomenut u knjizi Franza Schramla Kriegsschauplatz Kroatien (F. SCHRAML, 1962, 259). Ondje se donosi podatak da su zarobljena dva člana posade koja su izvučena iz zrakoplova koji je sletio na more. Također, navodi se da je jedan od zarobljenih pilota pokušao pobjeći u Brinju, ali je ponovno uhvaćen. (F. SCHRAML, 1962, 259). O okolnostima pada i sudbinama zarobljenih pilota vidi O. CLUTTONBROCK - R. CROMPTON, 2013, 162. 


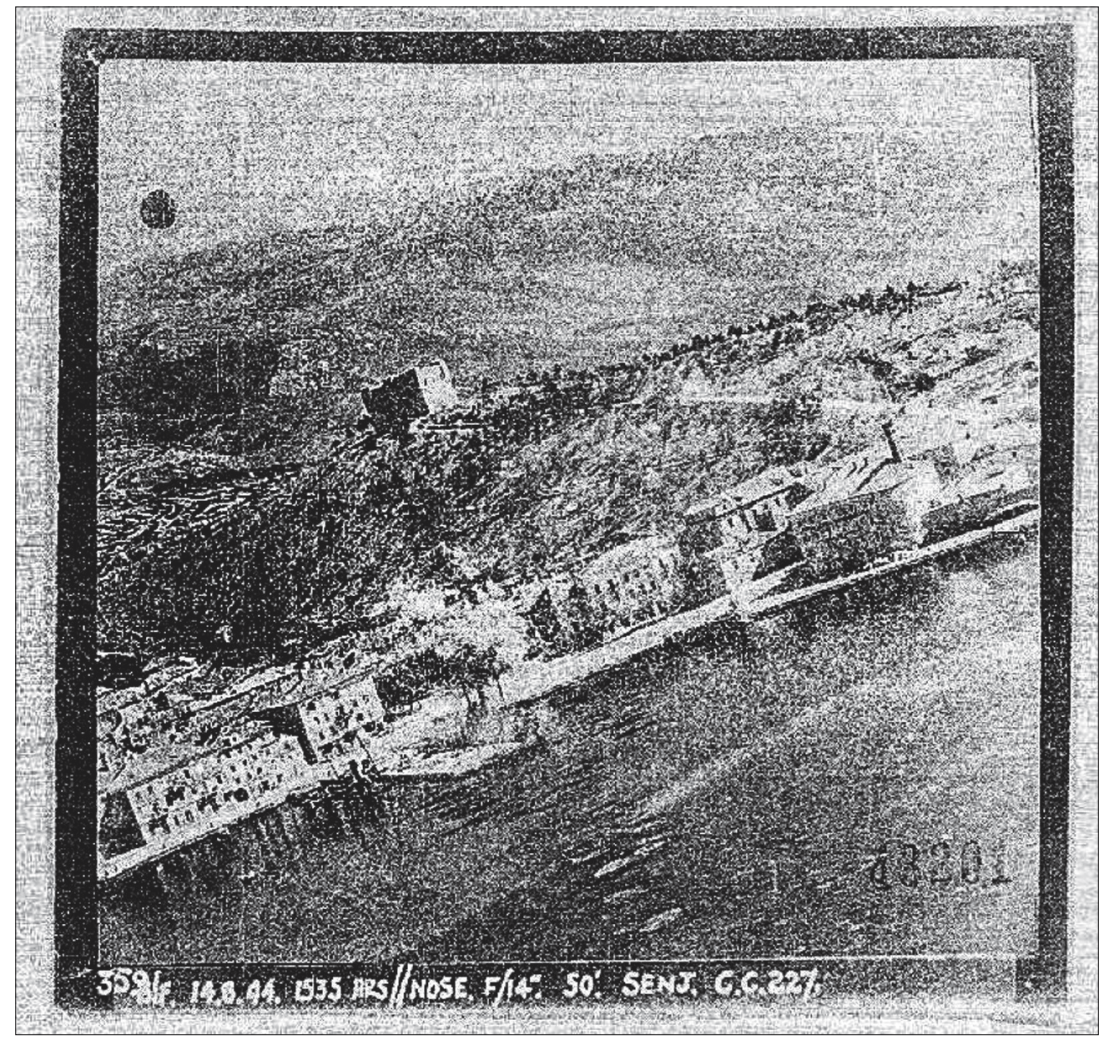

S1. 6. Arpione privezan uz gat Sv. Nikole na fotografiji napada 14. kolovoza 1944. zabilježenoj kamerom u nosu jednog od Beaufightera koji su sudjelovali u napadu (izvor: zbirka Tinusa Le Rouxa)

Kako bi priča bila intrigantnija, sasvim je izvjesno da je taj Bristol Beaufighter oboren pri napadu na istovjetni cilj koji se pokazao nesavladivom preprekom i za njihove kolege iz eskadrile F/Lt. Vancea i Lt. Medalieja otprilike dva mjeseca kasnije. To je bio njemački brod Arpione, za kojeg se, s popriličnom sigurnošću, može utvrditi da je boravio u senjskoj luci u kolovozu 1944. godine. ${ }^{43}$

${ }^{43}$ U partizanskom izvješću o bombardiranju Senja 14. i 15. kolovoza 1944. stoji: "Rezultat bombardovanja Senja 14.8.44: parobrod koji je podizan u luci ponovo otišao na dno ... 15. 8 ponovljeno bombardovanje Senja, rezultat: zapaljen brod dizalica, pogođena tvornica duhana i uništen magazin soli." (Zbornik dokumenata $i$ podataka o narodnooslobodilačkom ratu jugoslovenskih naroda, tom 5, knj. 31, 510, bilj. 137). Izvjesno je da se pod pojmom "parobroda koji je podizan u luci" misli na parobrod Istra na čijem je izvlačenju radio Arpione odnosno "brod dizalica" koji je zapaljen u napadu 15. kolovoza 1944. godine. 
Paralela između ta dva događaja istaknuta je i fotografijom napada snimljenom 14. kolovoza 1944. prednjom kamerom jednog od zrakoplova koji su sudjelovali u operaciji, a na kojoj se, koliko to dopušta malo lošije stanje očuvanosti, mogu uočiti vizure Arpionea privezanog na južnoj strani središnjeg gata Sv. Nikole, dakle na istom mjestu gdje se su ga F/Lt. Vance i Lt. Medalie napali 10. listopada 1944. (Sl. 6.). Položaj u trenutku snimanja fotografije pokrenutim otvaranjem topovske vatre po brodu sugerira smjer napada na brod sa sjeverozapada, od istočne obale Krka, stoga, s obzirom na lokaciju srušenog Beaufightera te opis misije, može se pretpostaviti da je Arpione napadnut iz istog smjera i dva mjeseca kasnije, kobnog listopadskog popodneva. ${ }^{44}$ Primjetno je da su i oba napada izvedena u gotovo isto vrijeme, popodne između 15 i 16 sati, a zanimljiv je i podatak da su četiri pilota (W/O Abbott, F/O Buxton; W/O. Davis, Sgt. Sefton) koji su sudjelovali u misiji 14. kolovoza 1944, također bili uključeni u napad 10. listopada 1944. godine..$^{45}$ Prema tome, čini se da su, nažalost, po lošim i tragičnim iskustvima i Senj i Arpione bili dobro zapamćeni među pripadnicima 19. eskadrile SAAF-a.

\section{Povijest broda Arpione}

Sudeći prema iznesenim podatcima, Arpione je "preživio" najmanje dva okršaja sa Beaufighterima 19. eskadrile SAAF kojima je pružio žestok otpor i uz manju štetu izbjegao potapanje.

Činjenica da je taj njemački brod često boravio u senjskoj luci otvara pitanje njegove svrhe i zadatka ondje, a tu nepoznanicu osvjetljuju prikupljeni podatci o njegovom životopisu i ratnom putu. Izgrađen je 1924. u brodogradilištu Deutsche Werft u Hamburgu kao ribarski brod pod imenom Cefalo te isporučen talijanskoj ribarskoj kompaniji SA Italiana Industria Pesca e Sottoprodoti iz Rima u okviru ratne reparacije Italiji. Godine 1933. Cefalo je preuzela kompanija za pomorska spašavanja Sorima (Societa Ricuperi Marittimi) iz Genove te ga preimenovala u Arpione i prenamijenila u remorker i spasilački brod, koji je zajedno sa druga dva broda iste vrste, $\mathrm{u}$ to vrijeme, činio flotu najboljih na svijetu u svojem poslu. Početkom rata Arpione je vjerojatno rekviriran za potrebe talijanske ratne mornarice. Nakon kapitulacije Italije, kako ne bi prešao u ruke

${ }^{44}$ Velika je vjerojatnost da je i napad 10. listopada 1944. fotografski dokumentiran, no te se fotografije nisu pronašle.

45 Izvješće o borbenom letu 10.10.1944. (Sortie Report No. 43146) (http://www. nationalarchives.gov.uk) (2019-11-14); Izvješće o borbenom letu 14.8.1944. (Sortie Report No. 43201) (http://www.nationalarchives.gov.uk) (2019-11-22). 
Nijemaca, namjerno je potopljen u tršćanskoj luci 8. rujna 1943. Međutim, kasnije je uspješno podignut s dna te uključen u službu Njemačke ratne mornarice (Kriegsmarine). ${ }^{46}$ Vjerojatno je i u novoj službu zadržao ulogu spasilačkog broda (Bergungsschiff) jer upravo ta svrha potvrđuje razlog njegova boravka u senjskoj luci. Naime, u njemačkom bombardiranju Senja u listopadu 1943. pogođen je parobrod Istra koji je bio privezan uz glavnu senjsku rivu. Međutim, zbog nevelike dubine mora, nije sasvim potonuo već se lijevim bokom nagnuo na dno, dok je veći dio palube ostao iznad površine mora. ${ }^{47} \mathrm{~S}$ obzirom na to da ga partizanska mornarica nije uspjela popraviti i povratiti u službu, Nijemci, koji su zauzeli Senj u siječnju 1944., uvidjeli su priliku za njegovu obnovu i osposobljavanje za plovidbu. Neprestano djelovanje savezničkog zrakoplovstva utjecalo je na kritičnu situaciju manjka brodova i nametalo potrebu za stalnim nadopunjavanjem aktivne flote. Stoga je razumljivo da je iz tih razloga i Arpione kao spasilački brod koji je radio na izvlačenju potopljenog parobroda često boravio u Senju tijekom druge polovice 1944.

U tom kontekstu, veliku vrijednost ima fotografija snimljena u ljeto 1944. godine koja prikazuje potopljeni parobrod Istra nasuprot kojeg je Arpione, privezan uz južnu stranu glavne senjske rive (gata sv. Nikole), dakle, na istom mjestu gdje se nalazio prilikom zračnih napada "južnoafričkih" Beaufightera u kolovozu i listopadu 1944. godine (S1. 7.). Na fotografiji pažnju privlači položaj dvocijevnog 20-milimetarskog protuzrakoplovnog topa Flak smještenog na krmi s koje se pruža izvanredna vizualna kontrola nad lukom i Senjskim kanalom te pogled na bilo koju prijetnju koja bi mogla ugroziti brod iz tog smjera. Nema nikakve sumnje da je upravo vatrom otvorenom s tog položaja oboren Bristol Beaufighter 10. listopada 1944. godine. Uz manju štetu Arpione je preživio taj napad, ali gotovo mjesec dana kasnije sreća mu je okrenula leđa jer je u zračnom napadu 5. studenog 1944. zajedno s njemačkim minopolagačem Kiebitzom (ex. Ramb III) i još nekim brodovima potopljen u riječkoj luci. ${ }^{48}$

${ }^{46} \mathrm{Na}$ informacijama o "životopisu" broda Arpione zahvale upućujem Zvonimiru Freivogelu; http://www.paluba.info/smf/index.php?topic=7603.0;imode (2019-02-25).

${ }^{47}$ M. BILOVIĆ et al., 2010, 124; A. GLAVIČIĆ, 1984, 352.

${ }^{48}$ Arpione je bio duljine $45 \mathrm{~m}$ i širine 7,5 m, kapaciteta $186 \mathrm{nrt}$, s pogonom na trocilindrični parni stroj trostruke ekspanzije snage $450 \mathrm{KS} \mathrm{s} 115$ okretaja u minuti. Nakon punih osam godina na dnu riječke luke, Brodospas ga je izvadio 1952. godine i nakon što je temeljito obnovljen, dobio je ime Vez te je prvo 1954. predan Jugoslavenskoj ratnoj mornarici, a potom ga je ona 1957. ustupila Upravi pomorstva Split. Od 1963. godine vlasnik broda je Pomorska škola Zadar koja ga je preimenovala u Mornar, a 1968. prodala INI gdje je opremljen geofizičkim uređajima služio u potrazi za plinom. U rezalištu Brodospasa izrezan je 1973. godine. (Zvonimir Freivogel; http:// www.paluba.info/smf/index.php?topic=7603.0;imode) $(2019-02-25)$. 


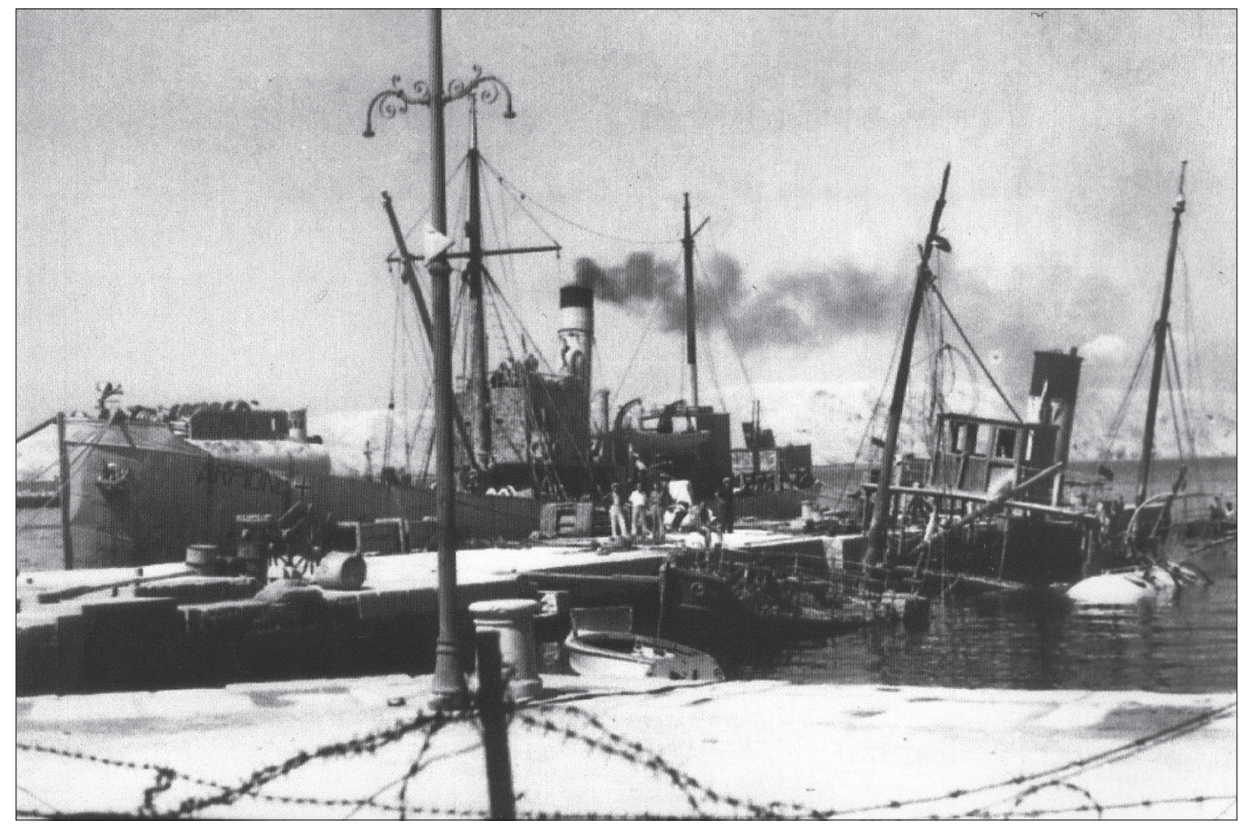

Sl. 7. Njemački brod Arpione privezan uz gat Sv. Nikole u senjskoj luci. Na krmi je vidljiv položaj dvocijevnog protuzrakoplovnog topa Flak. (izvor: privatna zbirka)

\section{Dokument o podijeljenom odlikovanju}

Potraga za njemačkim dokumentima i zapisima koji bi iz druge perspektive pružili novo svjetlo na priču o padu zrakoplova bila je neuspješna. Dodatni napori uloženi u pronalazak imena članova posade broda Arpione ili topnika koji se dokazao obaranjem zrakoplova nisu urodili rezultatima.

Međutim, o jednom podvigu izravno vezanom uz napad 10. listopada 1944. ostalo je pisano svjedočanstvo na dokumentu o podijeljenom odlikovanju. Prema iznesenim podatcima, 1. studenog 1944. general-poručnik Johann Mickl, zapovjednik 392. divizije, poznatije kao Plava divizija (Blaue Division), odlikovao je malom srebrnom medaljom za hrabrost (Kleine Silberne Tapferkeitsmedaille) Karla Baenscha, po činu starijeg vodnika (Hauptfeldwebel), pripadnika Druge inženjerijske bojne 392. divizije (2./Pi. Btl. 392) koji se iskazao prilikom zračnog napada "lovca-bombardera" ("Jabo-Angriff") na Senj u popodnevnim satima 10. listopada 1944. godine. Naime, jedna od raketa ispaljenih iz Bristol Beaufightera koji su sudjelovali u napadu probila je oplatu palube i pala u vatru brodskog kotla, ali pritom nije eksplodirala. Vodnik Baensch se zavukao u potpalublje, 
odvojio dio rakete s eksplozivnim punjenjem te ga odnio van broda $\mathrm{i}$ bacio $\mathrm{u}$ more. Njegova odlučnost i požrtvovnost bili su od ključne važnosti za spas broda jer je postojala velika mogućnost da vatra iz brodskog kotla aktivira eksplozivno punjenje i učini nepopravljivu štetu na brodu. ${ }^{49}$

\section{Zaključak}

Intrigantna priča o Bristol Beaufighteru NT997 koja otima zaboravu jedan tragični ratni događaj bez sumnje zaslužuje svoje mjesto u prezentaciji senjske povijesti kao svojevrsni podsjetnik na nepredvidivi i okrutni ratni vihor koji se nošen zvukovima tutnjave zrakoplovnih motora i fijucima bombi nadvio nad Senjem u Drugom svjetskom ratu. Dijelovi srušenog zrakoplova, poput mnogih drugih koji leže zaboravljeni u zagrljaju plave grobnice Jadrana, danas su prepušteni propadanju, uništavanju i nesavjesnim postupcima znatiželjnih ronilaca, stoga bi trebalo pronaći način da se stanje olupine dokumentira te da se ona primjereno zaštiti. Posmrtni ostatci članova posade, F/Lt. Alana Russella Vancea i Lt. Alexandra Morrisa Medalieja nikada nisu pronađeni, a njihova pogibija trajno je komemorirana na spomeniku Malta Memorial podignutom u čast savezničkih pilota stradalih u službi Commonwealtha, gdje se među više od 2200 komemoriranih imena mogu pronaći i ona njihova. ${ }^{50}$

Uspomeni na Lt. Medalieja posvećena je i elegija palom vojniku i dragom prijatelju, koju je 1945. godine objavila Olga Kirsh, poznata južnoafrička pjesnikinja židovskog podrijetla. ${ }^{51}$ Međutim, u Senju ne postoji prigodno obilježje i mjesto pada nije komemorirano premda je pjeskovito dno Senjskog

${ }^{49}$ Podatci o podijeljenom odlikovanju - obračun $b r$. 42956. Riječ o obračunu novčane nagrade koju je dobio primatelj odlikovanja, a na kojoj su opisane zasluge i pothvat za koji je odlikovan. Hptfw. Baensch odlikovan je malom srebrnom medaljom Ante Pavelića za hrabrost, koju mu je vjerojatno i osobno uručio general-poručnik Johann Mickl, zapovjednik 392. hrvatskonjemačke divizije koja je u to vrijeme kontrolirala široke prostore Like, Hrvatskog primorja i Podvelebitske obale od Senja do Karlobaga. General-poručnik Mickl smrtno je ranjen 9.4.1945. u partizanskoj zasjedi u Senjskoj Dragi dok je pokušavao novim snagama ojačati već znatno oslabljenu liniju obrane (A. GLAVIČIĆ, 2001, 212, bilj. 5). O okolnostima pogibije zapovjednika Mickla te boravku 392. divizije na senjskom području vidi F. SCHRAML, 1962, 229-277.

${ }^{50} \mathrm{https}$ //www.veterans.gc.ca/eng/remembrance/memorials/canadian-virtual-war-memorial/ detail/1533487 (2019-11-10); http://www.southafricawargraves.org/search/details.php?id=16312 (2019-11-10).

${ }^{51}$ E. ROTH, 2013, 106-107; T. MINNAAR - E. ROTH, 2014, 59-72. Pjesma je originalno napisana na afrikaansu i objavljena 1945. u studentskom časopisu WU's views sveučilišta Wits University, gdje je studirao i Alexander Medalie. Za cjelovitu pjesmu u originalnoj formi ili engleskom prijevodu (T. Minnaar) vidi E. ROTH, 2013, 106. 
kanala, prekriveno ostatcima srušenog zrakoplova, istinsko posljednje počivalište poginulih pilota. U skladu s time, žrtvama u čast, a nama na ponos, bio bi hvalevrijedan čin i važna civilizacijska gesta kada bi se na gatu Sv. Ambroza (Mađarskoj rivi), na lukobranu ili svjetioniku, nedaleko mjesta pada, postavila spomen ploča koja bi komemorirala taj događaj oplemenjena upečatljivim stihovima iz poeme "Resurrexit":

"He who perished in a high plume of flame and dark smoke - the rubble extinguished in the waves - has no ear for the smothered bell of death."
(Onaj koji poginuše u visokom oblaku plamena i mračnog dima - ruševine ugašene u valovima - nema sluha za prigušeno zvono smrti).

(Olga Kirsh, Resurrexit)

\section{Izvori i literatura}

\section{Izvori}

Circumstantial Loss Report $581438 \mathrm{~V}$ Lt. Alexander Morris Medalie No. 19 Squadron SAAF, Documentation Centre South African National Defence Force (Pretoria)

No. 5 Missing \& Research Enquiry Unit, 23rd March, 1948, Library and Archives Canada (Ottawa)

Military Service Record 581438 V Lt. Alexander Morris Medalie No. 19 Squadron SAAF, Documentation Centre South African National Defence Force (Pretoria)

Podatci o podijeljenom odlikovanju, br. 42956, Hptfw. Karl Baensch, 2./Pi. Btl. 392., 1.11.1944. (privatna kolekcija P. Domines Peter).

Ratni dnevnik 19. eskadrile Južnoafričkog ratnog zrakoplovstva (SAAF), listopad 1944.

(War diary of No. 19 Squadron, October 1944)

Zbornik dokumenata i podataka o narodnooslobodilačkom ratu jugoslovenskih naroda (ur. F. Trgo), tom 5, knjiga 31, Beograd, 1964.

\section{Knjige i članci}

Luka BEKIĆ, Krvavići - Boškina, Mjesto pada zrakoplova, u: Zaštitna arheologija na magistralnom plinovodu Pula-Karlovac (ur. Luka Bekić), Zagreb, 2007, 197211.

Mislav BILOVIĆ - Dragan VLAHOVIĆ - Antun VRHOVAC, Senj - stradanja u Drugom svjetskom ratu, Senj, 2010.

Leonard BRIDGEMAN, The Bristol 156 Beaufighter, u: Jane's Fighting Aircaft of World War II (ur. L. Bridgeman), London, 1946, 110-111. 
Oliver CLUTTON-BROCK - Raymond CROMPTON, The Long Road: Trials and Tribulations of Airmen Prisoners from Stalag Luft, Grub Street, London, 2014.

Danijel FRKA - Jasen MESIĆ, Blago Jadrana, ronilački vodič po olupinama hrvatskog Jadrana, Rijeka, 2012.

Antun GIRON, Senj - najznačajnija partizanska luka na Jadranu u razdoblju listopad 1943. - siječanj 1944., Senjski zbornik, 10-11, Senj, 1984, 319-322.

Ante GLAVIČIĆ, Njemačko bombardiranje Senja 1943. godine, Senjski zbornik, 10-11, Senj, 1984, 341-354.

Ante GLAVIČIĆ, Mjesta pogibije i pokapanja vojnika i civila tijekom Drugoga svjetskog rata i poraća na prostoru grada Senj i primorskih obronaka Kapele i Velebita od 1941. do 1946. (III. dio), Senjski zbornik, 28, Senj, 2001, 211-250.

Marica KARAKAŠ-OBRADOV, Angloamerička bombardiranja Hrvatske u Drugom svjetskom ratu, Zagreb, 2008.

Bristol Beaufighter I \& II, Leatherhead, Surrey, 1966.

Lovro PERŠEN - Mario RAGUŽ, Guerrilla Nightmare: Luftwaffe Stukas at War Against Tito's Partisans in Yugoslavia, 1941-1945, Lublin, 2018.

Kažimir PRIBILOVIĆ, Senj - baza II. pomorskog obalnog sektora mornarice NOVJ, Senjski zbornik, 6, Senj, 1975, 351-362.

Marko SINOBAD, Pad američkog bombardera B-24 kod Oklaja u Drugom svjetskom ratu, Titius: godišnjak za interdisciplinarna istraživanja porječja Krke, 6-7, Split, 2013-2014, 205-219.

Mihael SOBOLEVSKI, Bombardiranje Senja zrakoplovima u Drugom svjetskom ratu, Senjski zbornik, 30, Senj, 2003, 363-376.

\section{Internetski izvori}

ACHTUNG-STUKA, URL: https://gorgonija.com/2017/07/13/achtung-stuka/ (201905-20).

A.R. VANCE, URL: https://sites.google.com/site/famhistory001/home/arvance (201902-15).

JUTARNJI, Misteriozna smrt u dubinama, URL: https://www.jutarnji.hr/vijesti/hrvatska/ misteriozna-smrt-u-dubinama-dnk-analiza-otkrila-kome-pripadaju-kosti-nadenekod-otoka-visa/7144983/ (2019-02-20).

Thomas MINNAAR - Egonne ROTH, 'n Nuwe lewe: Olga Kirsch se studentegedig "Resurrexit", Werwinkel, 9 (2), Poznan, 2014, 59-72. URL: https://www. researchgate.net/publication/276242370_'n_Nuwe_lewe_Olga_Kirsch_se_ studentegedig_Resurrexit_A_New_Life_Olga_Kirsch's_Student_Poem_ Resurrexit (2019-3-22)

POMOĆNI BROD MORNAR, URL: http://www.paluba.info/smf/index. php?topic=7603.0;imode (2019-02-25). 
Egonne ROTH, Unassimilable Strangeness: The Afrikaans Poetry of Olga Kirsch, Werwinkel, 8 (1), Poznan, 2013, 101-123. URL: http://wa.amu.edu.pl/ werkwinkel/W_8-1/6_Roth.pdf(2019-3-23)

Franz SCHRAML, Kriegsschauplatz Kroatien; die deutsch-kroatischen LegionsDivisionen: 369., 373., 392. Inf.-Div. (kroat.) - ihre Ausbildungs-und Ersatzformationen, Neckargemünd, 1962.URL: http://znaci.net/00001/180.htm (2019-3-15)

Sortie Report No. 43146, No. 19 Squadron SAAF, 10th October, 1944 (http://www. nationalarchives.gov.uk, 2019-11-14).

Sortie Report No. 43201, No. 19 Squadron SAAF, 14th August, 1944 (http://www. nationalarchives.gov.uk, 2019-11-22).

SOUTH AFRICA WAR GRAVES PROJECT, URL: http://www.southafricawargraves. org/search/details.php?id=16312 (2019-11-10).

Steve STEVENS, Beaufighter Over the Balkans: From the Balkans Air Force to the Berlin Airlift, Barnsley, 2006.

THE AIRFORCE SQUADRONS, 19 SQUADRON, URL: http://www.saairforce.co.za/ the-airforce/squadrons/100/19-squadron (2019-02-22).

VETERANS AFFAIRS CANADA, URL: https:/www.veterans.gc.ca/eng/remembrance/ memorials/canadian-virtual-war-memorial/detail/1533487 (2019-11-10).

VRSAR-Ostaci potonulog zrakoplova, URL: https://www.min-kulture.hr/default. aspx?id=6212\&kdId=384781481 (2019-11-08).

\section{THE CRASH OF THE ALLIED BRISTOL BEAUFIGHTER AIRCRAFT (NT997) AT SENJ IN OCTOBER 1944}

\section{Summary}

The key military strategic position and exceptional transport, economic and military significance of Senj harbour were the reasons why during the Second World War Senj suffered air bombardments by the Germans and subsequently by Allied air forces which resulted in human losses and significant material damage. From the beginning of 1944, when Allied air forces gained supremacy in the air, all the way until the end of the war, Senj harbour and the harbour facilities were often targets of Allied tactical aerial bombardments, as well as the scenes of targeted attacks of fighters and fighter-bombers directed at small, specific and specially planned targets. In archive documents a large number of aerial attacks on Senj are noted, and during one mission by Allied air forces, on $10^{\text {th }}$ October 1994, during antiaircraft defence with the German ship Arpione in Senj harbour a Bristol Beaufighter NT997 fighter-bomber from the $19^{\text {th }}$ squadron of the South African Air Force (SAAF) was hit and crashed into the sea not far from the harbour. Illuminating the circumstances of the crash and fate of the members of the crew by analysing the remains of the plane and collected archive documents are the main aim of this paper which came to be upon the $75^{\text {th }}$ anniversary of this event.

Keywords: Second World War, Senj, plane crash, Bristol Beaufighter, Arpione 